\title{
The sensitivity of the ice-nucleating ability of minerals to heat and the implications for the heat test for biological ice nucleators
}

\author{
Martin I. Daily ${ }^{1}$, Mark D. Tarn ${ }^{1}$, Thomas F. Whale ${ }^{1 *}$ and Benjamin J. Murray1 ${ }^{1}$ \\ ${ }^{1}$ Institute of Climate and Atmospheric Science, School of Earth and Environment, University of Leeds, Leeds, LS2 9JT, UK \\ 5 *Current address: Department of Chemistry, University of Warwick, Gibbet Hill, Coventry, CV4 7AL, UK
}

Correspondence to: Martin I. Daily (m.i.daily1@leeds.ac.uk)

\begin{abstract}
Ice-nucleating particles (INPs) are atmospheric aerosol particles that can strongly influence the radiative properties and precipitation onset in mixed-phase clouds by triggering ice formation in supercooled cloud water droplets. The ability to distinguish between INPs of mineral and biological origin in samples collected from the environment is needed to better understand their distribution and sources, but this is challenging. A common method for assessing the relative contributions of mineral and biogenic INPs in samples collected from the environment (e.g., aerosol, rainwater, soil) is to determine the icenucleating ability (INA) before and after heating, where heat is expected to denature proteins associated with biological ice nucleants. The key assumption is that the ice nucleation sites of biological origin are denatured by heat, while those associated with mineral surfaces remain unaffected; we test this assumption here. We exposed atmospherically relevant mineral samples

15 to wet heat (INP suspensions warmed to above $90{ }^{\circ} \mathrm{C}$ ) or dry heat (dry samples heated to $250{ }^{\circ} \mathrm{C}$ ) and assessed the effects on their immersion mode INA using a droplet freezing assay. K-feldspar, thought to be the dominant mineral-based atmospheric INP type where present, was not significantly affected by wet heating, while quartz, plagioclase feldspars and Arizona test Dust (ATD) lost INA when heated in this mode. We argue that these reductions in INA in the aqueous phase result from direct alteration of the mineral particle surfaces by heat treatment rather than from biological or organic contamination. We 20 hypothesise that degradation of active sites by dissolution of mineral surfaces is the mechanism in all cases due to the correlation between mineral INA deactivation magnitudes and their dissolution rates. Dry heating produced minor but repeatable deactivations in K-feldspar particles but was generally less likely to deactivate minerals compared to wet heating. We also heat tested proteinaceous and non-proteinaceous biogenic INP proxy materials and found that non-proteinaceous samples (cellulose and pollen) were relatively heat resistant. In contrast, the proteinaceous ice-nucleating samples were highly sensitive to wet and dry heat, as expected, although their activity remained non-negligible after heating. We conclude that, while INP heat tests have the potential to produce false positives, i.e., deactivation of a mineral INA that could be misconstrued as the presence of biogenic INPs, they are still a valid method for qualitatively detecting proteinaceous biogenic INP in ambient samples, so long as the mineral-based INA is controlled by K-feldspar.
\end{abstract}




\section{Introduction}

30 In the absence of nucleation sites, cloud water droplets can supercool to temperatures below around $-35^{\circ} \mathrm{C}$ before freezing via homogeneous nucleation (Ickes et al., 2015; Herbert et al., 2015). However, a rare subset of atmospheric aerosol particles known as ice-nucleating particles (INPs) can elevate the temperature of ice formation (Murray et al., 2012; Hoose and Möhler, 2012; Kanji et al., 2017). INPs are important because newly formed ice crystals can grow at the expense of supercooled liquid droplets. This is a process that strongly modulates the radiative properties of shallow mixed-phase clouds (i.e., their albedo)

35 (Storelvmo and Tan, 2015; Murray et al., 2021), can initiate precipitation by enhancing collision and coalescence processes (Vergara-Temprado et al., 2018; Rosenfeld et al., 2011) and can influence anvil cirrus properties in deep convective systems (Hawker et al., 2021).

To represent the impact of INPs on clouds in our models, we must improve our understanding of the global distribution and 40 temporal variability of INPs. However, much uncertainty remains regarding the distribution, sources, and relative icenucleating ability (INA) of INPs throughout the Earth's atmosphere (Kanji et al., 2017; Huang et al., 2021; Murray et al., 2021). Two important general categories of INPs are mineral dust (Hoose et al., 2010; DeMott et al., 2003; Vergara-Temprado et al., 2017) and biogenic materials (Vergara-Temprado et al., 2017; Creamean et al., 2013).

45 Laboratory and field data indicate that mineral dusts often dominate the INP population relevant for mixed-phase clouds below around $-15{ }^{\circ} \mathrm{C}$ (O'Sullivan et al., 2014; Murray et al., 2012; Ansmann et al., 2008; Niemand et al., 2012; Ullrich et al., 2017). Potassium rich feldspars (K-feldspars) are considered to be the most important ice-nucleating mineral commonly present in airborne mineral dust (Atkinson et al., 2013; Harrison et al., 2019; Zolles et al., 2015; Augustin-Bauditz et al., 2014; Kaufmann et al., 2016), with immersion mode nucleation observed at temperatures warmer than $-5{ }^{\circ} \mathrm{C}$ in laboratory experiments (Harrison

50 et al., 2016; Kaufmann et al., 2016; Whale et al., 2017). Quartz and the other feldspar varieties plagioclase and albite are thought to play a lesser role than K-feldspar in terms of mineral dust INA (Harrison et al., 2019; Harrison et al., 2016; Atkinson et al., 2013), with quartz being on average the more abundant of these in the atmosphere (Murray et al., 2012).

Biological INPs are capable of nucleating ice at much warmer temperatures than all but the most active minerals, and can include primary biological particles such as bacteria, fungal spores, pollen grains, fragments of terrestrial organic material such as cellulose (Hiranuma et al., 2015b; Hiranuma et al., 2019) and macromolecules of marine biogenic origin (Schnell and Vali, 1976; Warren, 1987; Wilson et al., 2015; McCluskey et al., 2018). Compared to mineral dust, however, the sources, emission rates and atmospheric distribution of biogenic INPs are less well characterised (Huang et al., 2021; Kanji et al., 2017), owing to the diversity of marine and terrestrial sources that may be subject to seasonal variations (Conen et al., 2015; Schneider et

60 al., 2020; Šantl-Temkiv et al., 2019) or influenced by anthropogenic activities such as agricultural processes (Garcia et al., 2012; Suski et al., 2018; O'Sullivan et al., 2014). 
Atmospheric concentrations of ice-active bacteria, fungal spores and pollen grains are predicted to be smaller compared to mineral dusts (Hoose et al., 2010). However, the concentration of fragments of biogenic INPs may be much greater given the release of macromolecular INPs (Augustin et al., 2013; O'Sullivan et al., 2015) and their adsorption onto lofted soil dust (Schnell and Vali, 1976; O'Sullivan et al., 2016). Also, they tend to nucleate ice at temperatures where they may initiate secondary ice production processes (Morris et al., 2014; Field et al., 2017). Biogenic INPs could also play an important role in feedback processes in the rapidly warming Arctic climate, as increasing surface temperatures may expose new terrestrial sources in thawing permafrost (Creamean et al., 2020) or reveal new marine reservoirs as the sea ice coverage is reduced

70 (Hartmann et al., 2020).

Much effort in the past decade has been put into not only collecting and identifying biogenic INPs or their markers in the environment, but also in determining their relative contributions to the total measured INP population (Huang et al., 2021). This has been investigated using a number of techniques, including using microscopy (Huffman et al., 2013; Sanchez-

75 Marroquin et al., 2021) or instrumentation such as a waveband integrated bioaerosol sensor (WIBS) (Huffman et al., 2013; Suski et al., 2018), ultraviolet aerodynamic particle sizer (UV-APS) (Huffman et al., 2013), or an aerosol time-of-flight mass spectrometer (ATOFMS) (Pratt et al., 2009; Cornwell et al., 2019) to detect biogenic particles, or by genomic analysis to determine the presence and nature of known biogenic INPs (Garcia et al., 2012; Huffman et al., 2013; Hill et al., 2014; Christner et al., 2008).

While these techniques can reveal the presence of biological species in an aerosol sample that has been found to contain INPs, it remains difficult to assign ice-nucleating activity to these species over other constituents (e.g. mineral dusts) when a sample's INA is analysed by, for example, a droplet freezing assay alone. Genomic analysis is one of the few techniques that can truly identify a biological INP type, either by identification of known bacterial and fungal INPs through genetic sequencing, or via

85 the detection of the ina gene in ice-nucleating bacteria (Warren, 1987). However, sequencing does not detect INA characteristics, rather it is used to detect biological species that are already known to exhibit INA (Huang et al., 2021). On the other hand, detection of the ina gene does not necessarily indicate the presence of ice-nucleating proteins, and it also cannot be used to detect biogenic INPs that do not feature the gene (Garcia et al., 2012). Further, simply detecting the presence of biogenic INPs does not necessarily shed light on their INA contribution to a sample compared to other INPs that may be present, such as mineral dusts.

To date, no high-throughput technique has been established that can directly identify both the composition and nucleation temperatures of a specific INP type within a sample. However, a widely used methodology for performing an indirect assessment of the contribution of mineral vs. biogenic INPs involves treating a collected aerosol sample (or other INPcontaining media) with heat and comparing its INA spectrum before and after heating. Changes in INA can then be related to 
the presence and domination of biogenic INPs over inorganic INPs based on several assumptions, as discussed below. This heat treatment procedure has the advantages of being suitable for high-throughput offline sample analysis and does not require specialised equipment or the addition of reagents to selectively degrade biological material such as hydrogen peroxide (Suski et al., 2018; O'Sullivan et al., 2014; Tobo et al., 2019), lysozyme (Joyce et al., 2019; Henderson-Begg et al., 2009; Christner et al., 2008) or guanidinium hydrochloride (Conen and Yakutin, 2018). As such, it has been employed in the analysis of airborne aerosols (Conen et al., 2017; Šantl-Temkiv et al., 2019; Garcia et al., 2012), precipitation (Christner et al., 2008; Joyce et al., 2019; Michaud et al., 2014) and cloud water (Joly et al., 2014; Zinke et al., 2021), as well as possible sources and reservoirs of biogenic INPs such as soils (O'Sullivan et al., 2014; Hill et al., 2016; Conen and Yakutin, 2018; Conen et al., 2011), desert dusts (Boose et al., 2019; Paramonov et al., 2018), lakes and rivers (Pietsch et al., 2017; Knackstedt et al., 2018;

105 Moffett et al., 2018), and seawater (bulk water and sea surface microlayers) (Wilson et al., 2015; McCluskey et al., 2018; Creamean et al., 2019). We have compiled a list of studies and the heat test conditions that were used in each study in Table $\mathrm{S} 1$ in the Supplementary Information (SI).

The identification of the presence of biogenic INPs using this 'heat test' is based on the assumption that heat will inactivate

110 biogenic (often but not always explicitly proteinaceous) INPs, yielding a reduction in ice nucleation temperatures following the treatment, while the INA of inorganic INPs (likely to be dominated by mineral dust) will remain unaffected (Conen et al., 2011). In addition to merely determining the presence of biogenic INPs, this method has also been used by some researchers to quantify the abundance of biogenic INPs in their samples by evaluating the magnitude of the INA reduction (Christner et al., 2008; Joly et al., 2014; Joyce et al., 2019). The assumption that protein-bearing biological INPs associated with bacteria

115 and fungi can lose at least some of their INA when sufficiently heated (up to $100{ }^{\circ} \mathrm{C}$ ) has been confirmed via many previous studies (Lundheim, 2002; Pummer et al., 2015; Roy et al., 2021) (see the review of Lundheim (2002) for an overview). However, non-proteinaceous biogenic INPs, for example polysaccharides from pollen (Pummer et al., 2012; Pummer et al., 2015; Dreischmeier et al., 2017) and lignin (Bogler and Borduas-Dedekind, 2020), can retain their original INA when heated to temperatures over $200{ }^{\circ} \mathrm{C}$. In contrast, the assumption that mineral particles acting as INPs cannot lose any INA when subjected to heat treatment has yet to be thoroughly tested, while the question of whether a mineral reacts differently to being heated while suspended in water or while heated in air has not been addressed at all. Zolles et al. (2015) measured the change in INA of feldspars, quartz, kaolinite and Arizona Test Dust (ATD) after dry heating to $250{ }^{\circ} \mathrm{C}$ and observed only minor reductions within instrumental error. No similar surveys exist for wet heating, the more commonly used form of heat treatment of samples, although a small proportion of studies that employed the wet heat test for biological INP detection included control 125 tests with mineral suspensions including K-feldspar (O'Sullivan et al., 2014), montmorillonite (Conen et al., 2011), kaolinite (Hara et al., 2016; Hill et al., 2016) and ATD (Yadav et al., 2019). No significant changes in INA were observed in these examples except for ATD by (Yadav et al., 2019), who attributed this to the removal of an unspecified organic ice-nucleating material from the surface of the mineral. 
130 Finally, several studies have demonstrated the apparent lability of mineral INP kept in deionised water at room temperature over hours to days, wherein the immersion mode INA gradually decreased, which has been observed with samples of Kfeldspar (Harrison et al., 2016; Peckhaus et al., 2016), quartz (Harrison et al., 2019; Kumar et al., 2019a) and ATD (Perkins et al., 2020). It is reasonable to predict that elevated temperatures could accelerate the 'ageing' behaviour seen with these minerals leading to an INA deactivation on the timescale of a biological INP heat test.

Overall, this highlights that the potential for the false positive 'detection' of biogenic INPs through the loss of mineral INA when using heat treatments has yet to be ruled out. Here, we aim to validate the heat test in its current form by fully characterising how mineral INPs respond to heating both in air and in water compared to biogenic INPs. We achieve this via a laboratory study in which we tested the immersion mode INA of a set of atmospherically relevant mineral samples before

140 and after two types of heat treatment. We also performed equivalent tests on a set of biogenic INP analogue samples for direct comparison to the mineral INP results and as a positive control to ensure that the heat treatments would reproduce the known heat sensitivity behaviour of biogenic INPs.

We employed two methods of heat treatment: (1) direct heating of the sample in aqueous suspension (wet heating), and (2) heating the sample while in dry powder form prior to immersion in water (dry heating). This enabled us to investigate whether the deactivation behaviour of a sample depends on the medium in which it is heated, as previous studies have either involved heating samples in the wet or dry modes but not both. Our rationale for this is that an INP sample's potential chemical or physical reactions to heating in water or air may differ as these are fundamentally different treatments. Where possible, we also characterise the heat sensitivity of the important subclasses of mineral INPs and then discuss how this could affect

150 interpretations of biogenic INP heat test results and how this can inform us in the development of a more robust protocol. Further, we speculate on the physical reasons for the changes in INA found in our results, which may prove useful for future studies on the fundamental mechanisms of how mineral surfaces nucleate ice. This work may also be pertinent to emerging practical applications for mineral-based ice-nucleating agents in fields such as cell cryopreservation (Daily et al., 2020; Wragg et al., 2020; Morris and Lamb, 2018).

\section{2. Materials and methods}

\subsection{Sample selection}

A set of atmospherically relevant ice-nucleating materials was assembled into two broad classes of "mineral" and "biogenic" for heat treatment experiments. The mineral class comprised samples of ground minerals (either purchased from vendors in a milled form or milled in-house from a bulk mineral using a planetary ball mill) and commercially available dust proxies.

160 Details of the identity, provenance and purity of each of these are provided in Table 1. Most emphasis was placed on the feldspar and silica classes of minerals as these have previously been shown to be the most ice-active mineral classes in 
immersion mode freezing experiments (Atkinson et al., 2013; Harrison et al., 2019; Peckhaus et al., 2016) and therefore likely control the INA of a mineral dust assemblage of mixed mineralogy. Several of our samples have been analysed in the past using the same method and instrumentation as we employed here (Atkinson et al., 2013; Whale et al., 2017; Harrison et al.,

165 2016; Harrison et al., 2019) and of these only Atkinson Quartz showed a deviation (slight loss in activity) in INA since they were last tested. This indicates that the INA of the mineral samples remains largely stable while in storage. The remaining mineral samples were clay-based samples, the dust surrogates NX Illite and ATD and, finally, calcite.

The biogenic class of samples tested here included examples of proteinaceous material (Snomax ${ }^{\circledR}$ as a non-viable form of

170 Pseudomonas syringae bacteria, and lichen collected from trees in southern Finland) and non-proteinaceous material (microcrystalline cellulose (MCC) powder and silver birch pollen). Their sources are provided in Table 2.

Table 1: Sample information for mineral-based INP samples. Sources of data for purity and specific surface area (SSA) are detailed in the annotations.

\begin{tabular}{|c|c|c|c|c|}
\hline Sample name & Classification & Source & Purity $(\%)$ & SSA $\left(\mathrm{m}^{2} \mathrm{~g}^{-1}\right)$ \\
\hline BCS-376 Microcline & K-feldspar & Bureau of Analysed Samples, UK & $80.1^{\mathrm{a}}$ & $1.86^{\mathrm{a}}$ \\
\hline $\begin{array}{l}\text { BCS-376 Microcline (re- } \\
\text { milled) }\end{array}$ & K-feldspar & Bureau of Analysed Samples, UK & $80.1^{\mathrm{a}}$ & 2.59 \\
\hline TUD\#3 Microcline & K-feldspar & TU Darmstadt, Germany & $80.0^{\mathrm{b}}$ & $2.94^{\mathrm{b}}$ \\
\hline Amazonite Microcline & K-feldspar & University of Leeds mineral collection & No data & No data \\
\hline Eifel Sanidine & K-feldspar & University of Leeds mineral collection & No data & $1.1^{\mathrm{c}}$ \\
\hline Pakistan Orthoclase & K-feldspar & University of Leeds mineral collection & No data & No data \\
\hline TUD\#2 Albite & Plagioclase feldspar & TU Darmstadt, Germany & $90^{\mathrm{b}}$ & $1.92^{\mathrm{b}}$ \\
\hline BCS-375 Albite & Plagioclase feldspar & Bureau of Analysed Samples, UK & $76.6^{\mathrm{a}}$ & $5.8^{\mathrm{a}}$ \\
\hline Atkinson Quartz & Quartz & University of Leeds mineral collection & $99.9^{\mathrm{d}}$ & $4.2^{\mathrm{d}}$ \\
\hline Fluka Quartz & Quartz & Honeywell/Fluka (Cat No 83340), UK & $99^{\mathrm{d}}$ & $0.9^{\mathrm{d}}$ \\
\hline Fused Quartz & Quartz & $\begin{array}{l}\text { Goodfellow (Cat No. SI616010, } 45 \mu \mathrm{m} \text { ), } \\
\text { UK }\end{array}$ & $>99^{*}$ & No data \\
\hline Bombay Chalcedony & Quartz & University of Leeds mineral collection & $>99^{\mathrm{d}}$ & $1.23^{\mathrm{d}}$ \\
\hline KGa-1b Kaolinite & Clay based & Clay Minerals Society, USA (KGa-1b) & $96^{\mathrm{a}}$ & $13.6^{\mathrm{a}}$ \\
\hline Fluka Kaolinite & Clay based & Fluka (Cat No. 03584) & $82.7^{\mathrm{a}}$ & No data \\
\hline Sigma Montmorillonite & Clay based & Sigma Aldrich (Cat No. 69907), UK & $57.0^{\mathrm{a}}$ & No data \\
\hline SWy-2 Montmorillonite & Clay based & Clay Minerals Society, USA & $75^{\mathrm{a}}$ & $91.4^{\mathrm{a}}$ \\
\hline Chlorite & Clay based & University of Leeds mineral collection & $99.6^{\mathrm{a}}$ & $25^{\mathrm{a}}$ \\
\hline Arizona Test Dust (ATD) & Dust surrogate & $\begin{array}{l}\text { Powder Technology Inc., USA (A1 Ultra } \\
\text { fine) }\end{array}$ & - & $85^{\mathrm{e}}$ \\
\hline NX Illite & Dust surrogate & Arginotec, B+M Nottenkamper, Germany & - & $104.2^{\mathrm{f}}$ \\
\hline Calcite & Carbonate & University of Leeds mineral collection & $99.6^{\mathrm{a}}$ & $6^{\mathrm{a}}$ \\
\hline
\end{tabular}

175 References: a. Atkinson et al. (2013), b. Peckhaus et al. (2016), c. Whale et al. (2017), d. Harrison et al. (2019), e. Bedjanian et al. (2013), f. Broadley et al. (2012), * Data from manufacturer 
Table 2: Sample information for biological-based INP samples.

\begin{tabular}{lll}
\hline Sample name & Classification & Source \\
\hline Snomax ${ }^{\circledR}$ (freeze-dried, non-viable Pseudomonas & Proteinaceous & York Snow, Inc., USA \\
syringae bacteria) & Proteinaceous & Collected from trees around Hyytiälä Forestry \\
Lichen (Evernia prunastri) & & Station, Finland \\
& & Pharmallerga, Czech Republic \\
Birch pollen (Betula pendula) washing water (BPWW) & Non-proteinaceous & Sigma-Aldrich, UK (Cat. No. 435236) \\
Microcystalline cellulose (MCC) & Non-proteinaceous &
\end{tabular}

\subsection{Sample preparation}

180 All aqueous suspensions were prepared in $0.1 \mu \mathrm{m}$ pre-filtered, cell culture-grade deionised water (HyClone ${ }^{\mathrm{TM}} \mathrm{HyPure}$, GE Lifesciences). Suspensions of mineral samples of $1 \% \mathrm{w} / \mathrm{v}$ concentration were prepared by mixing $0.1 \mathrm{~g}$ of sample with $10 \mathrm{~mL}$ water in $20 \mathrm{~mL}$ borosilicate glass vials (Samco type T006/01, Surrey, UK), which had been pre-sterilised by dry heating at $175^{\circ} \mathrm{C}$ for $2 \mathrm{~h}$. The suspensions were thoroughly dispersed on a vortexer for 10 seconds after mixing and were gently inverted by hand several times to ensure even mixing before each drawing of the suspension via an electronic pipette. Glass vessels, rather than polypropylene centrifuge tubes, were used for all experiments unless stated due to their higher thermal conductivity when placed in a water bath (see Appendix A) and resistance to oven heating. The biogenic samples of Snomax ${ }^{\circledR}$ and MCC were prepared as $1 \% \mathrm{w} / \mathrm{v}$ suspensions using the same protocol as the mineral samples, while the birch pollen and lichen samples could not be immediately dispersed in water and so required additional processing steps.

A suspension of birch pollen washing water (BPWW) was prepared to a previously described protocol (O'Sullivan et al., 2015),

190 wherein a $2 \% \mathrm{w} / \mathrm{v}\left(20 \mathrm{mg} \mathrm{mL}^{-1}\right)$ suspension of raw pollen powder was prepared by weighing $0.2 \mathrm{~g}$ of raw pollen and adding to $10 \mathrm{~mL}$ deionised water, before mixing via vortexing and shaking, and being allowed to soak overnight at $4{ }^{\circ} \mathrm{C}$. The suspension was then filtered through a $11 \mu \mathrm{m}$ nylon net filter and then a $0.2 \mu \mathrm{m}$ cellulose acetate filter to remove the pollen grains, leaving only the washing water containing macromolecular INPs, thought to be anionic polysaccharides (Dreischmeier et al., 2017), for analysis.

195 The lichen sample (Evernia prunastri) was collected from a tree during a field campaign at the Hyytialla Forestry Station, Finland, in April 2018 and was air dried and then stored in a sealed sterile plastic bag at $4{ }^{\circ} \mathrm{C}$. The dried lichen was cut into millimetre-sized pieces, then $5 \mathrm{~mL}$ of purified water added to yield a lichen concentration of $2 \% \mathrm{w} / \mathrm{v}$ and placed on a rotary inverter for $2 \mathrm{~h}$ on a slow setting. The suspension was then filtered as per the BPWW procedure above to produce an aliquot of washing water ready for analysis. The baseline INA of this sample was first tested in August 2018 (U. Proske, unpublished

200 dissertation data) using a microlitre droplet assay (described below). When tested using identical methodology in February 2020 for this heat treatment study, its INA was found to be unchanged. 


\subsection{Heat treatments}

Each INP sample was subjected to heat treatment using two distinct methods: a 'wet heating' treatment wherein the INP was heated while in suspension and a 'dry heating' treatment wherein the INP sample was heated in dry powder form and subsequently mixed with water for analysis.

\subsubsection{Wet heating}

The 'wet heating' treatment comprised of a sealed vessel containing the INP suspensions, described in Section 2.2, being immersed in an open boiling water bath (hence at the boiling point of water at $1 \mathrm{~atm}: 100{ }^{\circ} \mathrm{C}$ ). The vessels were sealed tightly to prevent the evaporation of water from the vessel causing an increase in concentration of the suspensions. After $30 \mathrm{~min}$ of immersion, the vessel was removed from the water bath and then allowed to cool to room temperature prior to the droplet freezing assay. In the case of the washing water samples (i.e., BPWW and lichen), the wet heat treatments took place following the filtration steps.

The temperature profile of the liquid inside $20 \mathrm{~mL}$ borosilicate glass vials and $50 \mathrm{~mL}$ polypropylene centrifuge tubes (Corning

215 Falcon 352090) throughout the wet heat treatment procedure was measured (Fig. A2 in Appendix A) by inserting a thermocouple (Type K) through a small hole punched in the caps of the vessels, and was recorded using a data logger (TC-08, $\pm 0.025{ }^{\circ} \mathrm{C}$, Pico Technology, UK). This showed that a $10 \mathrm{~mL}$ liquid aliquot inside the glass vial reached a maximum temperature of $96^{\circ} \mathrm{C}$ after approximately $10 \mathrm{~min}$ of immersion in the boiling water bath, while the larger polypropylene vessel only reached $86{ }^{\circ} \mathrm{C}$ after $20 \mathrm{~min}$. Both vessels returned to ambient temperature approximately $45 \mathrm{~min}$ after being removed from the bath.

In addition to our standard 30 min heat treatment, we performed extended wet heat treatments of up to $24 \mathrm{~h}$ for selected samples by immersing the vessels in a silicone oil bath heated to $100^{\circ} \mathrm{C}$ rather than a water bath. The oil bath temperature was controlled using a thermostat alongside a magnetic stirrer bar and stirrer plate to ensure a homogeneous oil temperature.

\subsubsection{Dry heating}

'Dry heating' of samples was achieved by placing a $20 \mathrm{~mL}$ borosilicate glass vial containing a maximum of $0.2 \mathrm{~g}$ of dry sample in a standard laboratory oven at $250{ }^{\circ} \mathrm{C}$ for $4 \mathrm{~h}$, before being allowed to cool to room temperature and then prepared as an aqueous suspension as described in Section 2.2 above. The dry heat treatment for the BPWW was performed as described above but with a raw pollen-in-water suspension that was first evaporated to dry residue for the heat treatment, then resuspended in purified water. For the lichen sample, a small quantity of the raw lichen was cut up and placed in the borosilicate glass vial, heated in the oven as described, and the residue then suspended in deionised water. 
A temperature of $250{ }^{\circ} \mathrm{C}$ was selected for the dry heat treatment as it far exceeded the highest documented temperature at which the most heat resistant biogenic INPs (birch pollen at around $180{ }^{\circ} \mathrm{C}$ (Pummer et al., 2012)) are deactivated. Further, this temperature is lower than the maximum heat rating of polytetrafluoroethylene (PTFE) membrane and quartz filters that are often used to collect aerosol samples for INP analysis.

\subsection{Ice nucleation measurements by droplet freezing assay and determination of samples' heat deactivations}

The INA of the mineral-based and biogenic sample suspensions both before and after heat treatments was determined by performing immersion mode droplet freezing assays (Vali, 1971) using the Microlitre Nucleation by Immersed Particle Instrument ( $\mu \mathrm{L}-\mathrm{NIPI}$ ) (Whale et al., 2015), which has been used extensively for INP analysis in the literature and in several intercomparison studies (Hiranuma et al., 2015a; DeMott et al., 2018). Here, $1 \mu \mathrm{L}$ droplets (up to a maximum of 50) of INP suspension were pipetted onto a hydrophobic glass coverslip (22 mm diameter, cat. no. HR-231, Hampton Research, USA) that was located atop the aluminium cooling plate of a Grant-Asymptote EF600 cryocooler whilst at room temperature. The cooling plate was then enclosed in a Perspex chamber into which a flow of dry nitrogen gas was introduced at $0.3 \mathrm{~L} \mathrm{~min}^{-1}$ to flush the chamber of ambient air and to prevent the presence of moisture and airborne contaminants for the duration of each experimental run. The droplets were cooled at a rate of $1^{\circ} \mathrm{C} \mathrm{min}^{-1}$ until all of the droplets were frozen. Droplet freezing events were detected visually using an optical camera (Microsoft LifeCam HD) mounted atop the clear Perspex flow chamber.

Analysis of the droplet freezing events allowed the determination of the fraction of droplets frozen as a function of temperature, $f_{\text {ice }}(T)$, as shown in Eq. (1), where $n(T)$ is the number of droplets frozen at temperature $T$, and $N$ is the total number of droplets in the assay.

$f_{\text {ice }}(T)=\frac{n(T)}{N}=1-\exp \left(-n_{s}(T) A\right)$

The $f_{\text {ice }}(T)$ plots for each sample before and after heat treatments are shown in Figs. S1 and S2 in the SI and we have included a selection of plots in Fig. 1a-d to illustrate notable examples of heat sensitivity (and insensitivity) in selected samples. For brevity, we have also plotted the same data in the form of boxplots of droplet freezing temperatures of mineral samples grouped by mineral class (Figs 2a, 3a, and 4a) and of biological samples (Fig. 5). Changes in INA resulting from the heat treatments were evaluated by calculating the freezing temperature shifts between them and determining whether the shifts were significantly larger than the instrumental error. This was simply taken as the difference between the median droplet freezing temperature $\left(T_{50}\right)$ of the samples before and after the heat treatments to give a $\Delta T_{50}$ value: $\Delta T_{50}{ }^{\text {wet }}$ for the wet heat treatment and $\Delta T_{50}{ }^{d r y}$ for the dry heat treatment. Droplet freezing temperatures detected by the $\mu$ L-NIPI instrument have a nominal error of $\pm 0.4{ }^{\circ} \mathrm{C}$ (Whale et al., 2015) so, as a simple test for significance, a change in $\Delta T_{50}$ by more than 3 times this $\pm 0.4{ }^{\circ} \mathrm{C}$ error (i.e., $\pm 1.2^{\circ} \mathrm{C}$ ) between $f_{\text {ice }}(T)$ curves qualified as a significant shift. A significant shift in $T_{50}$ to colder temperatures (i.e., a negative $\Delta T_{50}$ value) indicated a deactivation in INA of a sample in response to heating. Blank tests were performed with droplets of filtered deionised water at the beginning of each day of experiments to confirm no contamination was introduced 
by the process. The results of these blank tests are included in each of the $f_{\text {ice }}(T)$ curves in Fig. 1 and are also shown in each of the boxplot figures (Figs. 2-5) in the form of a range of $T_{50}$ values.

(a) K-feldspar (BCS-376 Microcline)

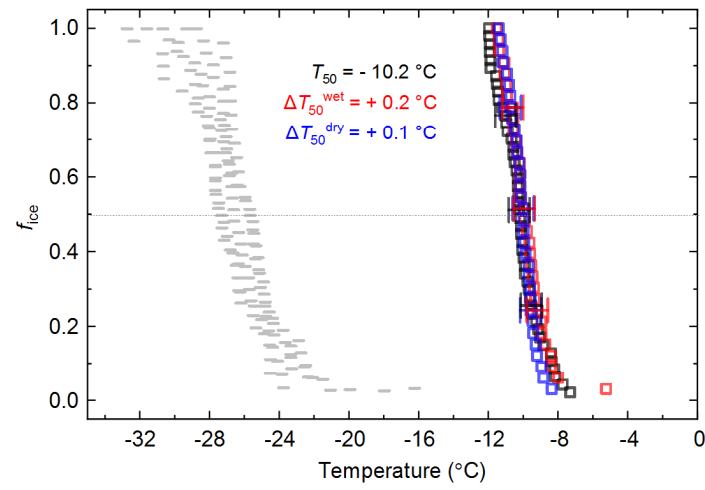

(c) Biological proteinacous (Snomax $\left.{ }^{\circledR}\right)$

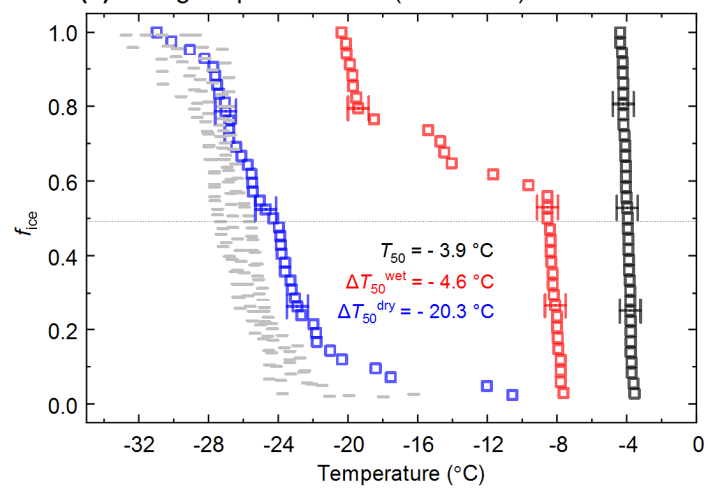

(b) Silica (Fluka Quartz)

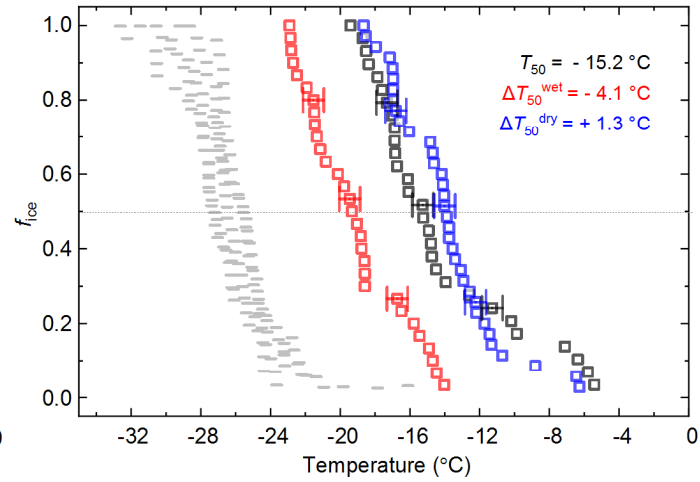

- No treatment

․ After wet heating

- After dry heating

Blanks (d) Biological non-proteinacous (Birch pollen washing water)

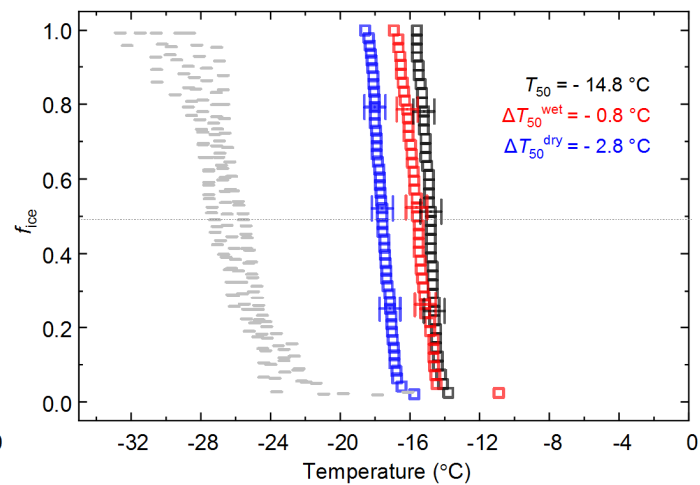

Figure 1. Fraction of droplets frozen $\left(f_{\text {ice }}(T)\right)$ spectra illustrating characteristic heat treatment responses for: (a) A heat-insensitive mineral INP (BCS-376 Microcline). (b) A wet heat-sensitive mineral INP (Fluka Quartz). (c) A heat-sensitive proteinaceous biological INP (Snomax ${ }^{\circledR}$ ). (d) A heat-insensitive non-proteinaceous biological INP (birch pollen washing water). On each plot, a dotted line is shown at $f_{\text {ice }}(T)=0.5$, at which $T_{50}$ temperatures can be read. Error bars on selected data points illustrate the $1.2{ }^{\circ} \mathrm{C}$ temperature range used to guide whether a shift in freezing temperatures after heating was considered to be significant.

Quantification of a nucleator's INA was achieved by determining the surface density of ice-active sites, $n_{\mathrm{s}}(T)$, of the sample, which allowed for comparison of our data with existing parameterisations for ice-nucleating materials (e.g., Fig $2 b$ for BCS376 Microcline). If the surface area of nucleant present in each droplet, $A$, is known, then this can be used to calculate $n_{\mathrm{s}}(T)$ of an INP sample from $f_{\text {ice }}(T)$, as shown in Equation (1). The surface area, $A$, in our samples was derived from measurements of the specific surface area (SSA, $\mathrm{m}^{2} \mathrm{~g}^{-1}$ ) of the INP powders obtained by the Brauner-Emmet-Teller (BET) $\mathrm{N}_{2}$ gas adsorption technique (e.g. (Harrison et al., 2019; Zolles et al., 2015; Paramonov et al., 2018). The SSA of the re-milled sample of BCS376 microcline K-feldspar was measured by BET (Micrometrics TriStar 3000), while literature values of SSA by BET were 
used for all other mineral samples. This assumes that each ice nucleation site has a characteristic temperature at which it always becomes active and time dependence is insignificant (Herbert et al., 2014), otherwise known as the singular description of heterogeneous ice nucleation (Koop and Zobrist, 2009; Murray et al., 2012; Vali, 1994; Pruppacher, 1978). Characterising icenucleating materials in terms of $n_{\mathrm{s}}(T)$ also forms the basis of models used for predicting the temperatures (and thus cloud regime) at which different classes of atmospheric INPs may become active (Vergara-Temprado et al., 2017; Hawker et al., 2021; Zhao et al., 2021; Murray et al., 2012).

\section{Results and discussion}

\section{3.1 Heat sensitivity of mineral-based INP samples}

\subsubsection{K-feldspars}

Alkali feldspars rich in potassium (K-feldspars) are considered to be the most important single ice-nucleating mineral component in atmospheric mineral dust due to their exceptional ability to nucleate ice in both immersion (Atkinson et al., 2013; Zolles et al., 2015; Harrison et al., 2019) and deposition mode (Yakobi-Hancock et al., 2013) in combination with its

290 ubiquitous atmospheric abundance (Arnold et al., 1998; Murray et al., 2012; Glaccum and Prospero, 1980; Kandler et al., 2009). As such, even in the presence of other minerals in higher proportions, the INA of a mineral dust will likely be controlled by the K-feldspar content (Harrison et al., 2016). We therefore dedicate particular focus to the heat test responses of this mineral in our study. We first discuss the wet heat tests, followed by the dry heat tests.

295 We included five different samples of K-feldspar in our survey (see Fig. 2a) in order to represent the diversity of this group of minerals. These included: BCS-376 Microcline, which was studied previously (Atkinson et al., 2013) and is considered generally representative of the INA of standard K-feldspars (Harrison et al., 2016); Amazonite and TUD\#3 Microcline, which are samples of microcline that show exceptionally high INA compared to typical variants of microcline and the other Kfeldspar polymorphs for reasons that are still unclear (Harrison et al., 2016; Welti et al., 2019; Peckhaus et al., 2016); Eifel

300 Sanidine, which exhibits much lower INA compared to the other samples due to a lack of cracks related to exsolution microtexture (Kiselev et al. 2021; Whale 2017\} and, in addition, we included a duplicate of the BCS-376 Microcline sample that was re-ground in a ball mill in order mitigate for possible 'ageing' of the sample and to investigate the effect of removing the largest particles in the sample.

305 In general, the INA of these samples did not respond substantially to wet heating for 30 mins with no significant reductions of $T_{50}$ in four out of five of the samples of K-feldspar (see Figs. 1a and 2a), An exception was Amazonite Microcline which showed a $\Delta T_{50}{ }^{\text {wet }}$ of $-1.5^{\circ} \mathrm{C}$, which was significantly greater than the experimental uncertainty, as defined above. The finding 
that K-feldspars are relatively insensitive to the wet heat test is consistent with the findings of O'Sullivan et al. (2014) and Peckhaus et al. (2016), who previously performed this test on BCS-376 Microcline and TUD\#3 Microcline, respectively.

We also conducted extended wet heat treatments of up to $22 \mathrm{~h}$ with BCS-376 Microcline that, although longer than typical biological INP heat tests, were designed to ascertain whether wet deactivation was possible. The results, shown in Fig. 2b, are plotted in the form of $n_{\mathrm{s}}(T)$ to enable comparison with literature data. The results show that $24 \mathrm{~h}$ of wet heating resulted in a reduction in $n_{\mathrm{s}}(T)$ of approximately one order of magnitude, or $2{ }^{\circ} \mathrm{C}$ at $n_{\mathrm{s}}(T)=1 \mathrm{~cm}^{-2}$. However, some deactivation of the most active sites appeared to occur after only $60 \mathrm{~min}$ of heating. After $3 \mathrm{~h}$, the reduction in $n_{\mathrm{s}}(T)$ was roughly the same as that seen after 16 months of immersion in water at room temperature, as determined by (Harrison et al., 2016). Overall, we find that the INA of K-feldspar is retained after short term (30 min) wet heating but can be reduced if heated for longer periods. These results show that the wet heat test results in no significant loss on INA in K-feldspars when heated for 30 min, but deactivation can occur when heated for longer periods of time.
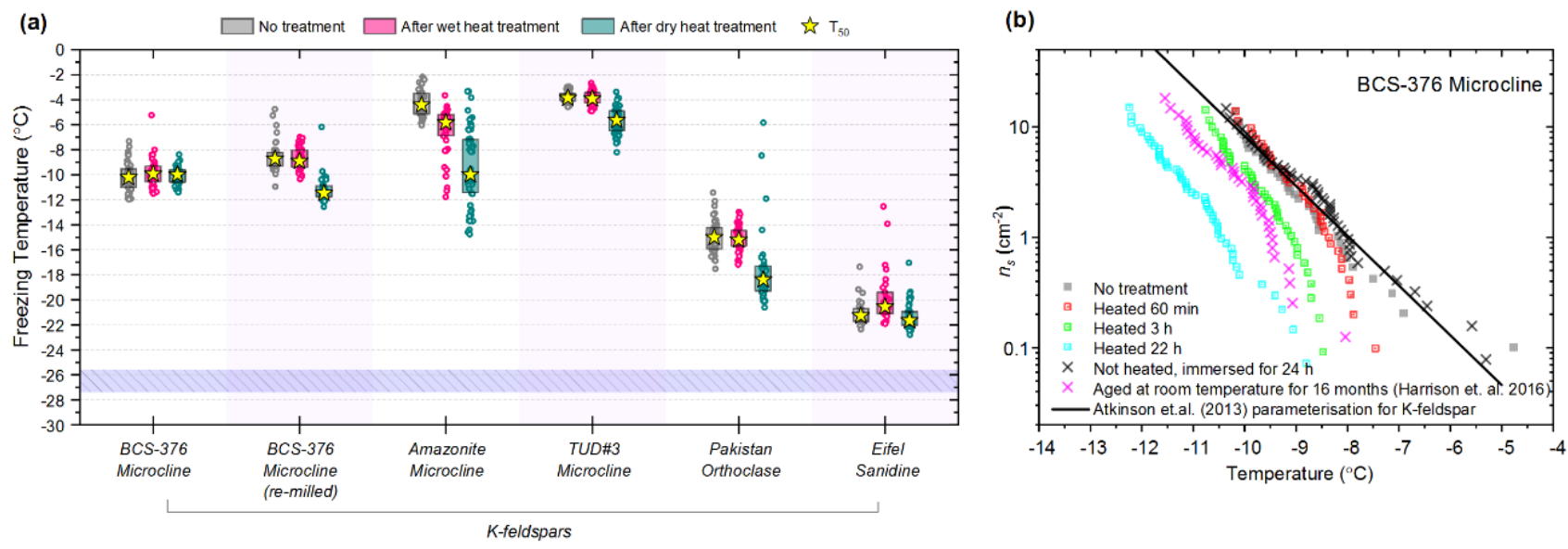

320 Figure 2. (a) Boxplot showing freezing temperatures before (grey) and after heat treatments (pink for wet heat, green for dry heat) for all K-feldspar samples. Boxes represent the $25-75 \%$ percentile, points represent individual droplet freezing temperatures, and stars represent the temperature at which half of the droplet population had frozen (i.e. $T_{50}$ ). Background freezing temperatures are illustrated by the blue band, which denotes the range of $T_{50}$ temperatures obtained from four blank droplet freezing runs. (b) Active site density per surface area $\left(n_{\mathrm{s}}(T)\right)$ spectrum for BCS-376 Microcline after extended wet heat treatment compared to room temperature ageing experiments from Harrison et al. (2016). The parameterisation for the ice-nucleating activity of K-feldpsar from Atkinson et al. (2013) is also shown.

To speculate on the reasons behind the deactivation of K-feldspar when wet heated for longer than 30 min, the nature of the ice-nucleating sites on minerals must first be considered. Ice nucleation on mineral surfaces such as feldspars has been shown to occur at specific sites that become active at a specific temperature (Holden et al., 2019; Holden et al., 2021). Topographical features associated with exsolution microtexture (Whale et al., 2017; Kiselev et al., 2021) have been proposed as the locations of the highly active sites on K-feldspar. Moreover, Kiselev et al. (2017) observed that ice crystals growing from the vapour phase on the surface of microcline originated on steps and cracks and were preferentially orientated between the basal face of ice and the (100) cleavage plane. More recent work suggests that cracks caused by exsolution microtexture may expose the 
(100) face of feldspars (Kiselev et al., 2021). The chemical and physical nature of these sites is still unclear, however molecular dynamics studies such as those by Pedevilla et al. (2017) show that having a high density of functional groups like silanol groups ( $\mathrm{Si}-\mathrm{OH})$, where water can hydrogen bond with the mineral surface and potentially order (such as those exposed at the (100) cleavage plane), may be important for nucleating ice (Harrison et al., 2019).

The most obvious physical cause of the INA deactivation of K-feldspar by wet heating would be the alteration of the mineral surface by dissolution via hydrolysis. This leaves an amorphous 'leached' layer at the surface (Lee et al., 2008; Chardon et al., 2006), destroying or at least disrupting the ice-active sites. Several studies have shown experimentally that acid treatment deactivates K-feldspar INPs (Augustin-Bauditz et al., 2014; Kulkarni et al., 2015; Kumar et al., 2018a). In pure water and at near-neutral $\mathrm{pH}$, however, the supply of $\mathrm{H}^{+}$for hydrolysis is lower and therefore the dissolution rate is much slower, but may still occur at the less stable, higher energy sites and topographic features (Parsons et al., 2015), which are themselves proposed as the highly active sites in K-feldspars. As discussed above, Harrison et al. (2016) observed a gradual INA deactivation of BCS-376 Microcline while at room temperature in deionised water, but this occurred over several months rather than hours. It is reasonable to propose that the same INA deactivation process observed by Harrison et al. (2016) also occurred on the Kfeldspar samples in this study but was accelerated in this case by heating.

Amazonite Microcline, one of our two highly ice-active microcline samples, was an exception to other K-feldspar samples in that short-term wet heating resulted in a significant but small deactivation $\left(\Delta T_{50}{ }^{\text {wet }}=-1.5^{\circ} \mathrm{C}\right)$. This could be because either the highly active sites of this sample were especially susceptible to dissolution and distinct from the more standard sites in the other K-feldspar samples, or is an indication of contamination with biological INPs. We return to this issue below.

Dry heating had a stronger deactivating effect on the K-feldspar samples than wet heating (Fig. 2a). Amazonite Microcline showed the largest $\Delta T_{50}{ }^{d r y}$ of $-5.6{ }^{\circ} \mathrm{C}$ and we observed that this sample lost its pale green colour and turned white following the treatment, becoming more similar in appearance to the other K-feldspar samples. Dry heating resulted in deactivation of the Pakistan Orthoclase $\left(\Delta T_{50}{ }^{d r y}\right.$ of $\left.-3.4^{\circ} \mathrm{C}\right)$ and produced smaller deactivations in TUD\#3 Microcline and the re-milled BCS376 Microcline samples $\left(\Delta T_{50}{ }^{d r y}\right.$ of $-1.8{ }^{\circ} \mathrm{C}$ and $-2.8{ }^{\circ} \mathrm{C}$, respectively). In contrast, the BCS-376 sample (prior to re-milling) did not deactivate on dry heating.

It is not clear why the re-milled sample of BCS-376 Microcline appeared slightly sensitive to dry heating while the original sample did not. We repeated the freezing assay three times, with the same result. Re-milling of the sample resulted in a decreased average particle size compared to the original sample with a corresponding increase in specific surface area (1.86 to $2.59 \mathrm{~m}^{2} \mathrm{~g}^{-1}$ in the re-milled sample). It appeared that the sites immediately after milling were more susceptible to dry heating than the sites that had been on a sample which was milled years previously. 
A potential alternative explanation is that there is a biological component mixed with the K-feldspar samples which nucleates ice and is deactivated on heating. The wet heating experiments and the lack of sensitivity of INA in these samples would indicate that any such biological ice-nucleating material must be non-proteinaceous. The dry heat test is a harsher treatment than wet heating in terms of temperature and duration and the deactivation we observe with wet heating may therefore be due to deactivation of non-proteinaceous biogenic material. Recalcitrant organic coatings have previously been proposed as the source of INA in mineral dusts that is lost upon dry heating (Paramonov et al., 2018; Peckhaus et al., 2016; Perkins et al., 2020). Peckhaus et al. (2016) did achieve a deactivation in TUD\#3 Microcline by treatment with hot aqueous $\mathrm{H}_{2} \mathrm{O}_{2}$ and suggested the presence of an organic ice-nucleating component, but concluded this was unlikely given the unrealistic mass of contaminant that would be required to produce such high ice-nucleating temperatures to start with. In the case of our affected

375 K-feldspar samples, non-proteinaceous biogenic material cannot be completely ruled out without further analysis, however there were no known candidates of organic non-proteinaceous heat-labile material that nucleate ice at such high temperatures. Hence, we tentatively suggest that the deactivation observed on dry heating K-feldspars is not related to biological material.

On the other hand, we can also speculate on reasons for dry heat deactivation of K-feldspars that are purely abiololgical. One candidate is an increase of the $\mathrm{Al} / \mathrm{Si}$ disordering of the $\mathrm{K}$-feldspar lattice, which can be achieved by dry heating of ground feldspar crystals (Cherry and Trembath, 1979). Although this process requires much longer timescales and higher temperatures (several weeks at $1025^{\circ} \mathrm{C}$ ) than used in our dry heat treatment, this procedure can transform microcline to sanidine. The degree of $\mathrm{Al} / \mathrm{Si}$ ordering has been proposed as a reason for the varying ability of K-feldspar polymorphs to nucleate ice (Welti et al., 2019) as, in general, disordered sanidines show the lowest INA while fully ordered microclines demonstrate the highest.

385 However, several exceptions to this rule have been reported (Harrison et al., 2016) and the higher INA of many microclines is related to the fact that they are more likely than sanidines to contain the exsolution microtexture thought to be to source of the highly active sites (Whale et al., 2017; Kiselev et al., 2021).

The loss of a (non-organic) volatile component during dry heating may alter K-feldspar in a way that reduces its INA. As described above, Amazonite Microcline is a green or turquoise coloured variant of microcline and was observed here to lose its green colouration upon dry heating. This phenomenon has previously been observed (Hofmeister and Rossman, 1985) and was correlated to the loss of water molecules that were structurally bound within the feldspar crystal lattice. Although Amazonite is a relatively rare variety of microcline, all feldspars contain a minor water component either as lattice-bound $\mathrm{H}_{2} \mathrm{O}$ molecules or $\mathrm{OH}$ groups or fluid pockets (Johnson and Rossman, 2003) that can be driven off by high temperature (Liu et al.,

395 2018), as could be the case in our dry heat treatment. Although it is not known whether this process would destroy the active ice nucleation sites, it is intriguing that microcline samples, the most ice-active variety, when surveyed were found to contain the most structurally bound water of all feldspars (Johnson and Rossman, 2004). 


\subsubsection{Plagioclase feldpsars}

Plagioclase feldspars are the most abundant mineral in the Earth's crust and are defined as having feldspar compositions between that of the $\mathrm{Na}$ endmember albite $\left(\mathrm{NaAlSi}_{3} \mathrm{O}_{8}\right)$ and the $\mathrm{Ca}$ endmember anorthite $\left(\mathrm{CaAl}_{2} \mathrm{Si}_{2} \mathrm{O}_{8}\right)$. Solid solutions between these two endmembers are more stable than in alkali feldspars, therefore plagioclase feldspars do not exhibit the 'perthitic' texture (exsolution microtexture) characteristic of K-feldspars. It has been suggested that the lack of these textures means that plagioclase feldspars are typically much less efficient INPs than K-feldspars (Whale et al., 2017).

405 We tested three samples of plagioclase (see Fig. 3a), two of which - BCS-375 Albite (Atkinson et al., 2013; Harrison et al., 2016) and TUD\#2 Albite (Peckhaus et al., 2016) - are predominantly composed of the albite endmember, and Labradorite - a plagioclase that features a Ca composition between $50 \%$ and $70 \%$ that of anorthite. BCS-375 Abite contains quartz (4.0 \%) and K-feldspar (16.7\%) impurities, while TUD\#2 Albite contains at least $90 \%$ plagioclase feldspar with the remaining $10 \%$ of the content being unknown (based on X-ray diffraction (XRD) data (Atkinson et al., 2013; Peckhaus et al., 2016)). The presence of K-feldspar in the former may mean that the observed activity is related to the presence of this component. No information is available on the mineral impurities present in the Labradorite sample. However, as plagioclase feldspar of labradorite composition is typically only found in basalts and gabbros, it is unlikely to coexist with quartz or K-feldspar since these rarely occur in these types of igneous rocks.

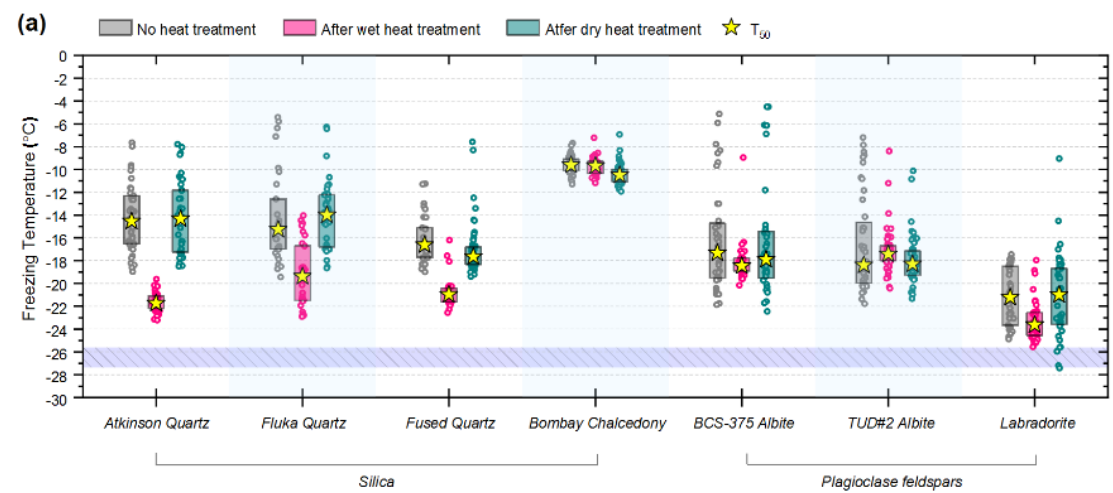

(b)

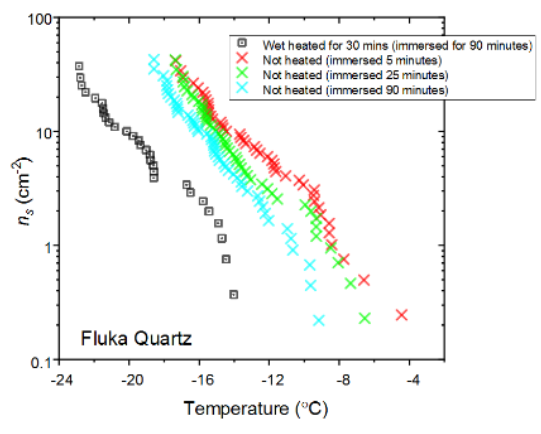

415 Figure 3. (a) Boxplot showing freezing temperatures before (grey) and after heat treatments (pink for wet heat, green for dry heat) for all quartz and plagioclase feldspar samples (b) $n_{\mathrm{s}}(T)$ spectrum comparing Fluka Quartz after wet heat treatment and room temperature ageing, illustrating their relative rates of INA deactivation.

BCS-375 Albite and TUD\#2 Albite showed no significant changes to their $T_{50}$ values after wet heating, but both samples lost much of the tail of INA that extended to above $-15{ }^{\circ} \mathrm{C}$ (Fig. 3a and Figs. S1g and S1h). Labradorite was sensitive to wet heating, with a $\Delta T_{50}{ }^{\text {wet }}$ of $-2.4^{\circ} \mathrm{C}$. All three samples in this mineral class were found to be insensitive to dry heat treatment, which means that biological contaminants was unlikely to be the source of the wet heat-labile INA (since all biological samples we looked at were sensitive to dry heat, see Section 3.2). The wet heat sensitivity was consistent with accelerated dissolution 
of the mineral surface, as discussed above for K-feldspars (and below for quartz). The Si dissolution rate for plagioclase feldspar is similar to that of quartz, but two orders of magnitude higher than that of K-feldspar microcline (Kumar et al., 2019a). This was consistent with the observation that, for example, both Labradorite and Fluka Quartz (see Sections 3.1.2 and 3.1.3) deactivated after $30 \mathrm{~min}$ of wet heating while BCS-376 Microcline took several hours to show deactivation. The wet heat reactions of the two albite samples were more difficult to interpret due to their varying impurities of other feldspars and quartz, and as such the deactivations could be a result of deactivation of those impurities rather than the plagioclase feldspar itself. However, Harrison et al. (2016) reported that a sample of highly ice-active albite (Amelia Albite), rapidly lost INA in water at room temperature over several days, which further indicates the general instability of plagioclase feldspars in water that may be accelerated by heating.

\subsubsection{Silicas}

Quartz is the most common crustal mineral after the feldspars and is also highly chemically and physically resistant to weathering. It is often a major component of soils and sediments and is the most abundant non-phyllosilicate mineral component of atmospheric mineral dust (Arnold et al., 1998; Murray et al., 2012; Glaccum and Prospero, 1980; Kandler et al., 2009). Quartz is the crystalline form of silica $\left(\mathrm{SiO}_{2}\right)$ and occurs in nature as several different polymorphs. However, $\alpha$-quartz is by far the most abundant polymorph and as such is usually referred to as 'quartz'. Previous laboratory studies have indicated that quartz particles have an atmospheric importance as INPs superior to that of clays but lower than alkali and plagioclase feldspars (Atkinson et al., 2013; Harrison et al., 2019), although there is variability in INA seen between different studies (Kumar et al., 2019a). Re-milling quartz powders has been seen to enhance their INA more than what may be expected based on the increase in surface area (Zolles et al., 2015), suggesting that the process creates active sites rather than simply exposing them. This has led to uncertainty as to whether the documented INA of quartz is representative of that found in the environment or whether it is simply an artefact of the laboratory milling process. The active sites of quartz are proposed to arise from fracturing that produce patches of 'dangling' $\mathrm{Si}$ - and $\mathrm{Si}-\mathrm{O}$ sites on the mineral surface that can readily hydroxylate and order water molecules. Another characteristic of quartz is that it can lose its INA while immersed in room temperature water over a few days (Kumar et al., 2019a; Harrison et al., 2019).

We included three samples of silica in the heat treatment study (see Fig. 3a): two $\alpha$-quartz samples - Atkinson Quartz and Fluka Quartz, and a sample of Fused Quartz, which is produced by melting quartz crystals then quenching to yield a glass (i.e. amorphous silica). We also included Bombay Chalcedony, which is composed of a cryptocrystalline intergrowth of quartz and moganite (another silica polymorph) and is notable as being the silica sample with the highest recorded INA (Harrison et al., 2019). We included this sample since its distinctly higher INA implies that the nature of the ice-active sites may be distinct from those of $\alpha$-quartz. Literature XRD data for our quartz samples indicate they are exceptionally pure in terms of mineralogy, with an $\alpha$-quartz content of at least $99.9 \%$ (Harrison et al., 2019). Fused Quartz, as stated by the manufacturer, has a silica content of $>99 \%$. 
Atkinson Quartz, Fluka Quartz and Fused Quartz all exhibited similar reactions to both wet and dry heat treatments (see Fig. 3a). In each case, the INA experienced significant deactivation upon wet heating $\left(\Delta T_{50}{ }^{\text {wet }}\right.$ of $-7.3,-4.1$ and $-4.4{ }^{\circ} \mathrm{C}$ for Atkinson Quartz, Fluka Quartz and Fused Quartz, respectively), but no significant changes when dry heated. In contrast, Bombay Chalcedony showed no significant change in INA following either type of heat treatment. Kumar et al. (2019a) proposed that in their study that the quartz INP suspensions deactivated only as an artefact of being contained in glass vessels, however when we repeated our wet heat treatment in plastic containers deactivation was still observed (see Figs. A1 and A2 in Appendix A for discussion). While the INA deactivation of quartz by dry heating has previously been described by Zolles et al. (2015), this is the first time that the wet heat treatment and resultant INA lability of quartz has been reported.

Being sensitive to wet heat, yet completely resistant to dry heat treatment, is an indirect but strong indication that the heat labile ice-nucleating sites on Atkinson Quartz, Fluka Quartz and Fused Quartz are not biological in nature. This is because our dry heat treatment would be expected to reduce the activity of both proteinaceous and non-proteinaceous biological INPs (as our results with biogenic materials show in Section 3.2). In addition, it is interesting that the glassy Fused Quartz sample had very similar responses to both dry and wet heat. This indicates that the active sites on these three silica samples are not dependent on crystallinity. Given that Bombay Chalcedony was the exception in this mineral class in that it was insensitive to heat, it seems that the active sites on this material were distinct to the other silica samples we studied. The high INA and stability to heat of Bombay Chalcedony is comparable to several of the K-feldspar samples. Bombay Chalcedony is also a microcrystalline material possessing micropores, much like K-feldspar, and this may give rise to stable active sites (Harrison et al., 2019).

Given the INA deactivation in silica samples upon heating appears to be abiotic and only occurs in water, but not dry heat, then the most obvious explanation is that it is due to the accelerated dissolution of surface features associated with the active sites. Active sites are thought to be most abundant where defects and fractures occur, as milling has consistently been found to increase the INA of quartz (Zolles et al., 2015; Kumar et al., 2018b; Harrison et al., 2019). They may also, however, be the most unstable sites as (Harrison et al., 2019) observed measurable 'ageing' in quartz samples (including Atkinson Quartz and Fluka Quartz) that were immersed in room temperature water for only $1 \mathrm{~h}$. Our wet heat treatment of Atkinson Quartz resulted in an INA deactivation of similar magnitude $\left(\Delta T_{50} 0^{\text {wet }}\right.$ around $\left.7{ }^{\circ} \mathrm{C}\right)$ to that achieved after 16 months of aqueous room temperature ageing by Harrison et al. (2019). To demonstrate the 'accelerated' deactivation speeds of quartz in water at different temperatures, we performed a parallel short-term room-temperature 'ageing' and wet heating experiment with Fluka Quartz, with the results shown in Fig. 3b. The heated sample and room-temperature sample had both been immersed in water for an equal amount of time, but the heated sample's $T_{50}$ was roughly $4{ }^{\circ} \mathrm{C}$ lower. This clearly showed that deactivation of the quartz was occurring in water at room temperature but was accelerated by heating. 
490 A similar apparent phenomenon of room-temperature ageing being accelerated by heating has also been observed for BCS376 Microcline K-feldspar (Harrison et al., 2016), except that the process appears to be much slower. At room temperature, INA deactivations of similar magnitude (up to $2{ }^{\circ} \mathrm{C}$ ) were observed after only $1 \mathrm{~h}$ for Atkinson Quartz (Harrison et al., 2019), compared to 16 months required for deactivation of BCS-376 Microcline (Harrison et al., 2016). Similarly, we needed to wet heat K-feldspar for at least $1 \mathrm{~h}$ to detect a small deactivation compared to $30 \mathrm{~min}$ for Fluka Quartz. However, crucially the deactivation of quartz is, unlike K-feldspar, fast enough to occur on a timescale relevant to biogenic INP heat tests (about 30 min). It is possible that the same deactivation mechanism for both K-feldspar and Atkinson Quartz occurs during the wet heat treatments and is consistent with active site degradation by surface dissolution for two possible reasons. Firstly, surface dissolution rates for quartz are faster than for microcline $\left(10^{-13}\right.$ to $10^{-12} \mathrm{Si}-\mathrm{m}^{-2} \mathrm{~s}^{-1}$ compared with $4 \times 10^{-14}$ to $8 \times 10^{-14} \mathrm{Si}-\mathrm{m}^{-2}$ $\mathrm{s}^{-1}$ at neutral $\mathrm{pH}$ and $25^{\circ} \mathrm{C}$ (Kumar et al., 2019b)). Secondly, quartz and feldspar break apart differently when ground. Quartz, lacking cleavage planes, fractures conchoidally, while feldspar can more easily cleave along its two perfect cleavages situated on the (001) and (010) faces. Fracturing rather than cleaving may result in a surface topography dense in high energy but unstable ice nucleation sites that are more susceptible to dissolution (Harrison et al., 2019).

\subsubsection{Clay-based mineral samples}

Clay minerals are present in abundance in soils, sedimentary and some metamorphic rocks, as well as in airborne samples of mineral dust. Clays fall into the phyllosilicate group of minerals, with its principal subgroups comprising kaolin (which includes kaolinite), smectite (which includes montmorillonite), illite and chlorite. They are secondary minerals, meaning that they are weathering products of igneous and metamorphic minerals and, as such, samples often contain relic traces of their parent minerals (for example K-feldspar in the case of kaolinite or illite) and also of quartz as a weathering reaction product. Clays were previously considered (Hoose and Möhler, 2012) to be the most important mineral ice-nucleating component of atmospheric mineral owing to early experimental work (Mason and Maybank, 1958) until the greater importance of feldspars was established (Atkinson et al., 2013). They are, however, still overall the most abundant type of mineral found in atmospheric mineral dust, their concentration tending to increase proportionally in transported dusts owing to their smaller particle size (Murray et al., 2012). Therefore, clay minerals may be more likely to control the INA of desert dusts sampled far from their source and of the finer particle fraction.

The study of the heat treatment of clays included two samples of kaolinite (KGa-1b Kaolinite and Fluka Kaolinite), two samples of montmorillonite (SWy-2 Montmorillonite and Sigma Montmorillonite) and one sample of chlorite (Chlorite). An illite-rich sample (NX Illite) was included, but this is discussed in the Mineral Dust Analogues Section (3.1.5). The clay samples showed variable responses to heat treatments, as is shown in Fig. 4a. It is important to note that the INA of these samples may be related to the varying amounts of quartz and feldspar impurities in the samples, hence we may well not be observing the heat sensitivity of the clay itself. 


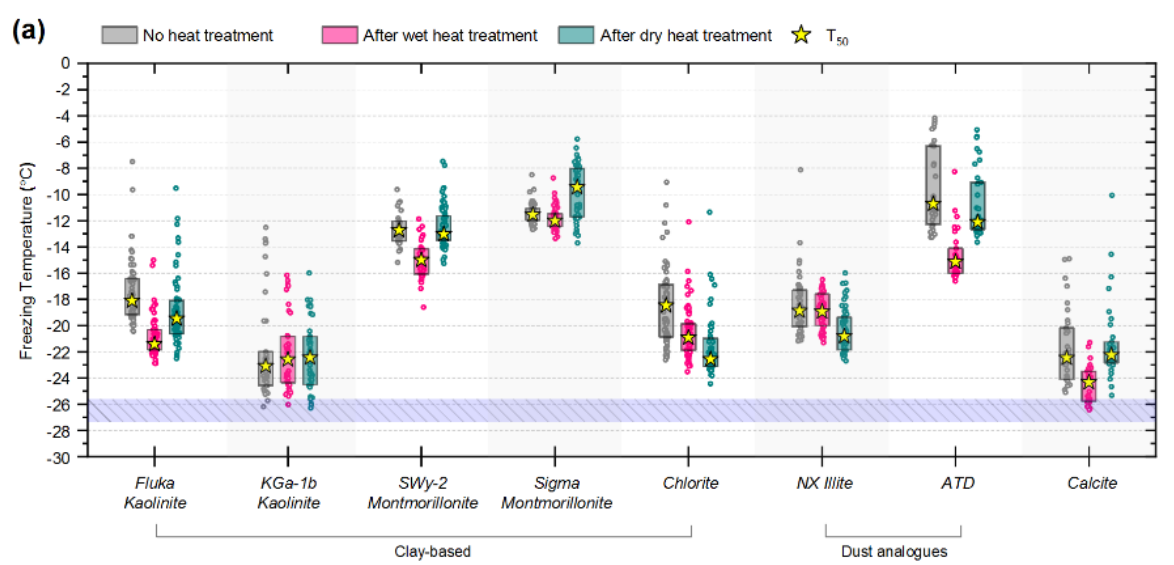

(b)

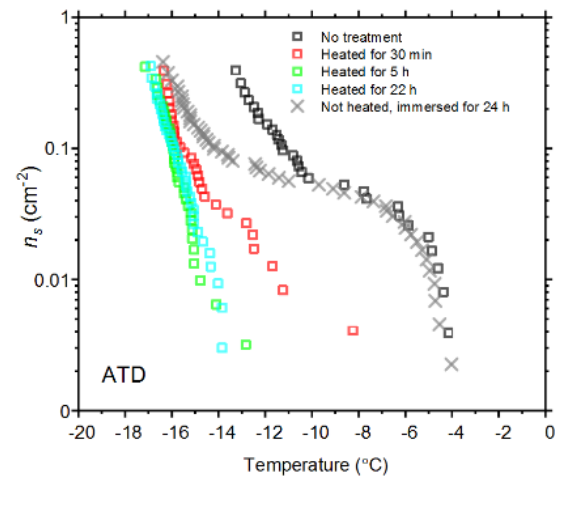

Figure 4. (a) Boxplot showing freezing temperatures before (grey) and after heat treatments (pink for wet heat, green for dry heat) for clays, mineral dust analogues and calcite. (b) $n_{\mathrm{s}}(T)$ spectrum showing ATD after extended wet heat treatments and room temperature ageing, illustrating their relative rates of INA deactivation.

While neither kaolinite sample were significantly sensitive to dry heat (the Fluka sample was only marginally sensitive), the Fluka Kaolinite showed clear sensitivity to wet heating while KGa-1b Kaolinite did not. We can perhaps attribute this to the comparatively purer state of the latter (96\% kaolinite) compared to the former $(83 \%)$ that includes a $6 \%$ component of quartz, which was shown to be sensitive to wet heating in Section 3.1.3.

The results for the montmorillonite samples were harder to interpret because both possessed quite low purities and showed responses to heat treatments that are not easily explained by their feldspar and quartz components. A notable result was that the INA of the Sigma montmorillonite sample increased after dry heat treatment. An increase in INA in the deposition mode after dry heating has previously been observed in a smectite-rich Saharan dust sample that had been dry heated at $300{ }^{\circ} \mathrm{C}$ for

$53510 \mathrm{~h}$ during a study by Boose et al. (2019). The authors discussed potential reasons for this, including the volatilisation and removal of an organic INA inhibiting coating, as well as purely inorganic processes such as the growth of new anhydrite crystals from gypsum in the sample or alterations to the lattice spacing of smectite clay. Our sample, which became more active upon heating, did not contain any gypsum impurities, hence conversion to the highly active anhydrite (Maters et al., 2020; Grawe et al., 2018) was not a possibility. Smectites are characterised by their ability to swell or shrink by taking up or

540 losing loosely bound water molecules in the crystal lattice. However, the same effect of dry heating was not observed for SWy2 Montmorillonite, which demonstrated no deactivation of INA with dry heating and only a minor deactivation upon wet heating. Hence, the changes in the INA of Sigma Montmorillonite during dry heating could not be related to its swelling properties. 
545 The results for chlorite, with its high purity (99.6\%), indicated heat-lability in both the wet and dry heat modes. However, chlorite likely has only limited atmospheric importance as an INP due to both its relatively low INA and typically low (around $5 \%$ ) proportional make-up of airborne mineral dusts (Murray et al., 2012; Kandler et al., 2009; Glaccum and Prospero, 1980).

\subsubsection{Mineral dust analogues}

Mineral dust analogue samples NX Illite and Arizona Test Dust (ATD) are two commercially available mineral dust mixtures that have been used as atmospheric mineral dust analogues in laboratory investigations into the properties of INPs (Marcolli et al., 2007; Broadley et al., 2012; Niemand et al., 2012; Hiranuma et al., 2015a). ATD contains a much higher proportion $(\sim 50 \%)$ of quartz and feldspars than NX Illite ( 20\%), with the remainder of both comprising clay minerals and a small amount of carbonate. It has been suggested that the INA of ATD may be artificially enhanced by the milling process used in its production (Perkins et al., 2020). Both mineral dust samples contain a higher proportion of K-feldspar than quartz (Broadley et al., 2012; Hiranuma et al., 2015a) meaning that K-feldspar should be the main contributor to the INA of both samples. This is consistent with the relatively high INA of ATD, in which the dominant polymorph of K-feldspar is microcline (Kaufmann et al., 2016). However, NX Illite is less active than would be expected given its K-feldspar content, which may be due to weathering or that the K-feldspar may have an INA at the lower end of the K-feldspar INA range (Harrison et al., 2016).

The boxplots with droplet freezing temperatures for NX Illite and ATD are show in Fig. 4a. NX Illite was unresponsive to wet heating, as was previously demonstrated by $\mathrm{O}^{\prime}$ Sullivan et al. (2015), but deactivated after dry heating with a $\Delta T_{50}{ }^{d r y}$ of -2.0 ${ }^{\circ} \mathrm{C}$. ATD was clearly deactivated by wet heating $\left(\Delta T_{50}{ }^{\text {wet }}\right.$ of $-4.5^{\circ} \mathrm{C}$, with activity almost eliminated above $\left.-10{ }^{\circ} \mathrm{C}\right)$ and slightly affected by dry heating $\left(\Delta T_{50}{ }^{d r y}\right.$ of $\left.-1.4^{\circ} \mathrm{C}\right)$. We further investigated the wet heat sensitivity of ATD by performing extended heat treatments of up to $22 \mathrm{~h}$ and also room-temperature ageing for $24 \mathrm{~h}$, and these are plotted as $f_{i c e}(T)$ in Fig. $4 \mathrm{~b}$. This shows

565 a similar behaviour to that observed for Fluka Quartz (Fig. 3b), where room temperature deactivation was observed but deactivation was greatly increased by heating. However, in the case of ATD, the sites active at above $-10{ }^{\circ} \mathrm{C}$ retained activity when immersed in room temperature water, while the activity of sites active at lower temperatures was reduced (Fig. 4b). A previous instance of the wet heating of ATD in the literature also showed at a wet heat lability (Yadav et al., 2019), while dry heating using a range of different methodologies also showed slight reductions in ATD's INA (Sullivan et al., 2010; Perkins et al., 2020; Zolles et al., 2015), thus corroborating the results shown here. Perkins et al. (2020) found that ATD lost some INA after dry heating to $500{ }^{\circ} \mathrm{C}$, yet was deactivated to roughly the same degree by 'ageing' in water at room temperature for 2 days. Both dry heating to $600{ }^{\circ} \mathrm{C}$ and aqueous oxidation treatment by boiling in $30 \% \mathrm{H}_{2} \mathrm{O}_{2}$ led to more significant deactivations. They attributed the dry heat deactivation to oxidation of an organic coating stable in air up to $500{ }^{\circ} \mathrm{C}$ but removed readily in the aqueous mode. They did not, however, boil the ATD in water alone which would have determined if the $\mathrm{H}_{2} \mathrm{O}_{2}$ deactivation was merely a result of being heated in water. 
As described above, K-feldspar is mostly only sensitive to dry heating while quartz is only sensitive to wet heating, which implies that the observed changes in INA for NX Illite may be controlled by the K-feldspar component while the INA of ATD may be controlled by milled quartz particles. Alternative explanations to the deactivations include biological contamination. However, similar to the results obtained for the silica samples, the greater deactivation seen in ATD from wet heating compared with that from dry heating suggests that the heat-labile component is not biological (see Section 3.2).

\subsubsection{Calcite}

Calcite $\left(\mathrm{CaCO}_{3}\right)$, along with other carbonates such as gypsum and dolomite, has been found to be an ineffective mineral INP (Atkinson et al., 2013; Zolles et al., 2015; Kaufmann et al., 2016), however it can often be the dominant component of some 585 surface dust sources, especially the deserts of north-western Africa (Knippertz and Stuut, 2014). The calcite sample displayed a reduction in INA after wet-heating $\left(\Delta T_{50}{ }^{\text {wet }}\right.$ of $\left.-1.9^{\circ} \mathrm{C}\right)$ but not after dry heating. This case was distinct from that of other minerals that were sensitive to wet heating (e.g., Fluka Quartz) where a similar degree of deactivation occurred in a control experiment when suspended in water at room temperature for the same duration as the heated sample (see Fig. S3). If the dissolution of active sites on calcite resulted in INA deactivation in water, then the fact that heating did not significantly speed up INA deactivation can be explained by calcite exhibiting retrograde solubility in water. Dissolution of calcium carbonate in water occurs when water equilibrates with atmospheric $\mathrm{CO}_{2}$ and forms weak carbonic acid. Hence, the solubility, and reduction in activity, is limited by the amount of $\mathrm{CO}_{2}$ dissolved in water, hence the lack of additional effects upon heating.

\subsection{Biological INP surrogates}

Four biological INP analogue samples were subjected to the same wet and dry heat treatments as the mineral-based samples and the results are summarised in Fig. 5 as boxplots and in Fig. S2 as $f_{\text {ice }}(T)$ curves. Snomax ${ }^{\circledR}$ and a lichen sample were used as examples wherein their INA is related to proteins. Snomax ${ }^{\circledR}$ is a snow inducer product composed of lyophilised protein derived from Pseudomonas syringae bacteria cultures and also used a surrogate for ice-nucleating bacteria (Wex et al., 2015; Polen et al., 2016). Bacterial ice nucleators' heat sensitivity is well characterised (Obata et al., 1989; Kunert et al., 2018), as is that of Snomax ${ }^{\circledR}$ (Tarn et al., 2018; Wex et al., 2015). The reduction in INA in bacteria upon heating has been associated with

600 a change of the beta-helix structure to a beta-sheet structure, indicating denaturation of the ice-nucleating proteins of the bacteria (Roy et al., 2021). Lichens are symbiotic associations of fungi and algae and have been found to contain highly active INPs that are proteinaceous and likely originate from the fungal component (Moffett et al., 2015; Kieft and Ruscetti, 1990). This was therefore used a convenient source of fungal ice-nucleating material, which have been found to have slightly higher heat resistance compared to bacterial INPs (Pummer et al., 2015; Pouleur et al., 1992; Fröhlich-Nowoisky et al., 2015). Pollen and cellulose based INP were chosen to represent non-proteinaceous biological INP sources where the INA is related to polysaccharide components. A sample of silver birch pollen (Betula pendula) was used to prepare an aqueous suspension of birch pollen washing water (BPWW). Pollen contains water-soluble ice-nucleating polysaccharide macromolecules (Pummer et al., 2012; Dreischmeier et al., 2017), which can be readily released into suspension with water (Augustin et al., 2013). 
Microcrystalline cellulose (MCC), a polysaccharide reagent derived from wood pulp, was used as a surrogate for detrital plant

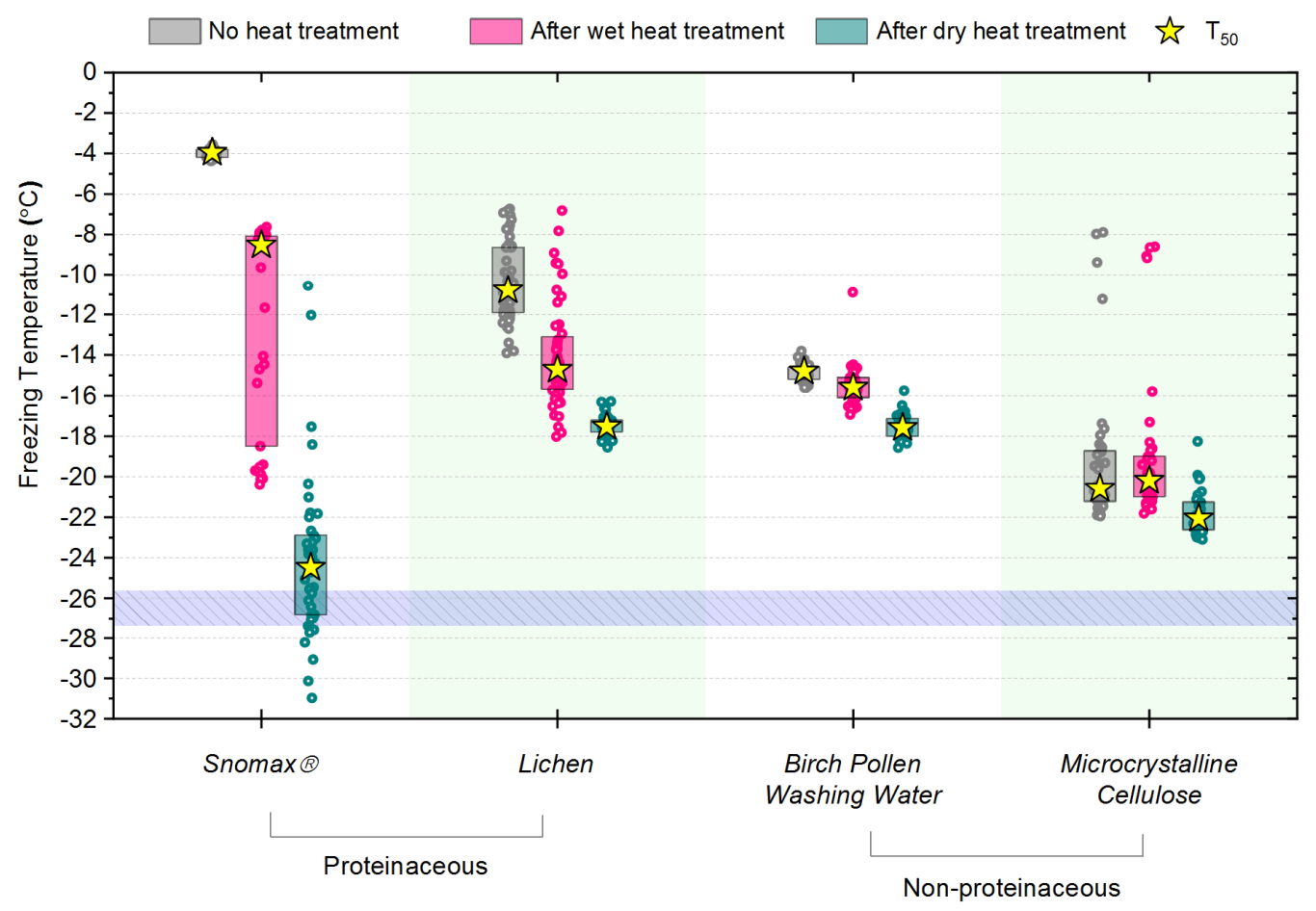

Figure 5. Boxplot showing freezing temperatures before (grey) and after heat treatments (pink for wet heat, green for dry heat) for biological INP samples.

Snomax ${ }^{\circledR}$ was not completely deactivated by wet heating but was reduced to near background levels by dry heating, with the material appearing carbonised (turning into a black substance) after the treatment. Clearly, the dry heat test was able to denature or destroy the ice-nucleating proteins in Snomax ${ }^{\circledR}$. However, these proteins were much more stable to the wet heat test. Just over $50 \%$ of the droplets still froze at around $-8{ }^{\circ} \mathrm{C}$, in contrast to $100 \%$ of the droplets freezing by $-5{ }^{\circ} \mathrm{C}$ in the non-heated sample. While there was clearly a deactivation in the wet heat test, a substantial proportion of the INA remained; this conflicts with the general assumption that ice-active proteins are fully denatured in the wet heat test. Lichen also showed stronger deactivation by dry heating compared to wet heating, although it still retained activity in a narrow range between $-16{ }^{\circ} \mathrm{C}$ to $-19{ }^{\circ} \mathrm{C}$ after the dry heat test. The lichen was also converted to a black substance by the dry heating process but, unlike Snomax®, it retained a significant INA, indicating that there was a very stable population of ice- nucleating entities that are much more stable than the proteins in bacteria. 
625 Microcrystalline cellulose was unchanged by wet heating but there was a minor deactivation $\left(\Delta T_{50}{ }^{d r y}\right.$ of $\left.-1.5^{\circ} \mathrm{C}\right)$ after dry heating, even though the material itself appeared physically unchanged. Birch pollen washing water was not significantly deactivated by wet heating, but the dry heat treatment of birch pollen left a dark brown residue on the inside of the glass vial, which did not appear to be readily dissolved or re-suspended when water was added to the vial for the subsequent drop assay. Remarkably, however, when the water that was added was analysed it showed a $\Delta T_{50}{ }^{d r y}$ of only $-2.0{ }^{\circ} \mathrm{C}$ compared to the non-

630 heated birch pollen, while preserving its characteristically narrow band of freezing temperatures (Tarn et al., 2020). These results are contradictory to those of Pummer et al. (2012), who also heated washings of birch pollen to dryness but achieved complete deactivation of INA by heating to $187^{\circ} \mathrm{C}$ for $1 \mathrm{~h}$, compared to the heating at $250{ }^{\circ} \mathrm{C}$ for $4 \mathrm{~h}$ in our experiment.

Overall, the results showed that the proteinaceous samples (Snomax ${ }^{\circledR}$ and lichen) clearly suffered substantial deactivation by

635 both the wet and dry heat treatments, while non-proteinaceous samples were not sensitive to wet heating and were only mildly sensitive to dry heating. Further, the proteinaceous samples exhibited much stronger INA deactivations as a result of dry heating. The stability of the INA in pollen and cellulose is consistent with reports of the relative resistance of polysaccharidebased ice-nucleating materials to heat (Conen et al., 2011; Conen et al., 2015; Bogler and Borduas-Dedekind, 2020). Clearly, the heat tests should not be considered as a general test for biological INPs, but can be used as a qualitative test for the presence of the subset of proteinaceous biological INPs.

\section{Summary and implications for using INP heat treatments}

We performed both wet and dry heat tests on a range of mineral and biological ice-nucleating materials and directly compared their characteristic INA responses to both heat treatments. The results are summarised in Table 3. Our findings show that the general assumption that the INA of minerals is insensitive to heat, while the INA of biological materials is sensitive to heat, is too simplistic. For example, quartz and plagioclase feldspar INPs were found to be sensitive to wet heating in a comparable way to proteinaceous INPs (e.g., from bacteria and lichen). The implication therefore is that reduced INA of mineral samples may be incorrectly attributed to biological INPs. In contrast, K-feldspars are generally insensitive to the wet heat test (with the exception of Amazonite, which happens to be a relatively rare type of microcline), as were the polysaccharide-based INPs. Kfeldspars and polysaccharide-based INPs are also only slightly sensitive to the dry heat test, meaning that the presence of nonproteinaceous biogenic INPs may be indistinguishable from K-feldspar via either heat treatment if proteinaceous INP are not also present. 
Table 3. Summary of the characteristic responses of classes of INPs to wet and dry heat treatments.

\begin{tabular}{lll}
\hline INP type & $\begin{array}{l}\text { Characteristic sensitivity of INA to wet } \\
\text { heating }\left(100{ }^{\circ} \mathrm{C} \text { for } 30 \mathrm{~min}\right)\end{array}$ & $\begin{array}{l}\text { Characteristic sensitivity of INA to dry } \\
\text { heating }\left(250{ }^{\circ} \mathrm{C} \text { for } 4 \mathrm{~h}\right)\end{array}$ \\
\hline $\begin{array}{l}\text { K-feldspar } \\
\text { Plagioclase feldspar }\end{array}$ & Stable $^{1}$ & Slightly heat sensitive ${ }^{2}$ \\
Quartz & Slightly heat sensitive & Stable \\
Clays & Heat sensitive & Stable \\
Carbonates & Stable & Stable \\
Biological, proteinaceous & Sensitive to water at room temperature & Stable \\
Biological, non-proteinaceous & Heat sensitive & Heat sensitive
\end{tabular}

Notes: 1. Hyperactive varieties may have slight sensitivity; 2 . Hyperactive varieties are very sensitive; 3 . Slight sensitivity in room temperature water; 4. Apart from chlorite; 5. Montmorillonite may increase in INA when dry heated; 6. INA deactivation does not increase when heated.

Crucially, since the INA of K-feldspar is not reduced by short-term wet heating (30 min), the wet heat test remains a valid method for distinguishing proteinaceous INPs from mineral dusts, so long as the INA of the mineral dust component is controlled by K-feldspar. Nevertheless, the INA heat lability of some commonly occurring minerals raises the possibility that a false positive detection of biological INPs could be made following a wet heat test, i.e., a loss of INA of quartz or plagioclase feldspar may be misconstrued as a loss of biological INA. This could occur during a scenario in which a wet heat test is performed on a sample whose mineral component INA is dominated by its silica or plagioclase feldspar content rather than Kfeldspar and in which proteinaceous biological INPs are absent. The importance of quartz and plagioclase feldspars as icenucleating components of mineral aerosols are second only to K-feldspar, hence the possibility of this scenario occurring should not be dismissed. However, feldspars and quartzes tend to be found together in desert dust assemblages, thus K-feldspar will likely control the INA of desert dust on most occasions.

The magnitude of the quartz heat sensitivity we observed should also be put into context. A demonstration of this can be seen in the report by Yadav et al. (2019), who performed wet heat tests on rainwater and dust samples collected from Northern India, with a heat test of ATD performed as a control. The results showed a resultant deactivation of INA that was consistent with our results. The authors attributed this to the presence of organic matter in their ATD sample. However, the magnitude of deactivation $\left(\sim 1^{\circ} \mathrm{C}\right)$ observed in the ATD control was far smaller than in their rainwater samples (up to $10^{\circ} \mathrm{C}$ ), which was interpreted as evidence of 'biological influence'. In other words, the 'signal' produced by the mineral INP heat deactivation should be weak compared to that of proteinaceous INP deactivation, hence the loss of INA in ATD may not have been influenced by the presence of biological components after all. Generally, marginal heat deactivations should be interpreted with caution and generally should not be attributed to the presence of proteinaceous ice-nucleating materials. This especially applies if heat deactivations have been used to calculate the ambient concentration of biological INPs in addition to identifying their presence. 
We also consider the issue of whether the heat-sensitive active sites we found in our mineral samples are an artefact of the milling process and therefore not representative of particles present in the environment. The INA of quartz (Kumar et al., 2019a; Zolles et al., 2015; Harrison et al., 2019) and hematite (Hiranuma et al., 2014) are increased by milling. This might imply that heat-labile mineral INPs do not occur naturally. Conversely, it has been argued that quartz particles in desert dusts are naturally 'milled' by collisions during the process of saltation prior to being lofted into the air (Harrison et al., 2019). If this is correct, then it would mean that only quartz INPs originating from desert dust, with their active surfaces exposed following saltation, would be wet heat-labile, whereas quartz particles that have been in contact with water, for example in soil or sediments, would have already been 'aged' and so may be less susceptible to further wet heat treatment.

Here, we provide some further caveats and considerations for the use of heat tests to identify biological, specifically proteinaceous, INPs in environmental and atmospheric samples:

Wet heating did not fully denature the ice-active proteins in Snomax®, whilst it also deactivated some mineral INPs (e.g., quartz and plagioclase feldspars) much more strongly than dry heating did. Therefore, dry heating of aerosol filters or any INP sample available in an initially dry form could be considered as an alternative or parallel heating method that is more selective than wet heat treatment. The dry heat sensitivity of K-feldspar could negate this approach, however using lower dry heating temperatures than that used in this study $\left(250{ }^{\circ} \mathrm{C}\right.$ for $4 \mathrm{~h}$ ) may avoid any deactivations in the minerals while still achieving full denaturation of proteinaceous material. Further experimentation would help to determine whether there is an optimal dry heating condition that enables a robust and practical protocol that achieves this.

\section{b) Control heat tests on mineral and biological INP references}

Relatively few of the previous studies (Conen et al., 2011; Hara et al., 2016; Hill et al., 2016; O'Sullivan et al., 2015; Tobo et al., 2014; Yadav et al., 2019) in which heat treatments were performed to identify the presence of biological INPs in the environment also included a control to test whether their protocol deactivated the INA of a mineral powder reference. Considering this study, future implementations of the heat test could benefit from testing a set of reference materials (e.g., microcline K-feldspar, albite plagioclase feldspar, quartz and Snomax ${ }^{\circledR}$ ), to 'calibrate' a specific heat

\section{c) Avoiding room temperature mineral deactivation}

An overlooked consequence of the wet heat treatment is that the INP sample may be immersed in water for longer than non-heated counterparts. This could result in an apparent deactivation of non-biological INPs due to the 'ageing' effects of mineral INPs in water (as demonstrated in this study and in the literature (Harrison et al., 2019; Kumar et al., 2019a), which we hypothesise are sometimes sped up by heating. Two adaptations to the method that could mitigate this include: (i) conducting tests on samples for room temperature 'ageing', similar to those for Fluka Quartz 
and ATD performed here; (ii) ensuring that all heated and non-heated samples are in immersed water for an equal duration before running tests for INA.

\section{d) Potential heat-based deactivations during hydrogen peroxide treatment}

While not explored in this study, hydrogen peroxide solutions have been used as a method to eliminate all organic matter from soil and dust INP samples (Suski et al., 2018; O'Sullivan et al., 2014; Tobo et al., 2019). However, this treatment typically uses moderate (e.g., $60^{\circ} \mathrm{C}$ ) to boiling water temperatures and, as such, may inadvertently result in quartz and plagioclase feldspar INA deactivation in samples lacking in K-feldspar, even without the influence of $\mathrm{H}_{2} \mathrm{O}_{2}$. Such a false positive could be mitigated by performing a control test in which the treatment is performed at the same temperature but without the presence of hydrogen peroxide.

\section{Conclusions}

In this study, we have tested and characterised the changes in ice-nucleating ability of the principal mineral components of desert dust in response to heat treatments in both wet and dry modes and in parallel with biological INP analogues (bacterial, fungal, pollen and cellulose). The main purpose of this was to assess the efficacy of heat treatments for the 'detection' of biological INPs in environmental sample media such as ambient aerosol, surface waters, soils and desert dusts. Understanding how the sources and distribution of biological INPs and mineral dust INPs differ in the environment may be crucial for understanding their current and future impact on the climatic impacts of clouds. It has been previously assumed that mineral INPs are inert to moderate heat treatments that are sufficient to denature proteins. However, we found that while the INA of (most) K-feldspars was unchanged on wet heating for $30 \mathrm{~min}$, as expected, quartz and plagioclase-rich feldspars were heatlabile. The INA of these samples was unchanged when exposed to dry heat $\left(250^{\circ} \mathrm{C}\right.$ for $\left.4 \mathrm{~h}\right)$. Given that proteinaceous INP samples (bacteria and lichen) were strongly deactivated by the dry heat test, it is clear that the loss of activity in quartz and plagioclase feldspars was related to the minerals themselves, rather than some biological contamination.

We suggest that the loss of INA on wet heating of quartz and plagioclase feldspars is related to aqueous dissolution of features

740 acting as active sites on the mineral surface. This is supported by the observation that the relative dissolution rates of the different mineral types correlate with their relative heat sensitivities. Moreover, several studies have previously reported aqueous room temperature 'ageing' of mineral INP samples and our results are consistent with the same process being accelerated by heating. As quartz and plagioclase feldspars are ubiquitous components of mineral dusts, this raises the possibility of false positives being produced by minerals in wet heat tests, which are more commonly used compared to dry

745 heat tests. However, if the mineral-based INA of an environmental sample being tested for INP is controlled by K-feldspar then wet heat tests are valid. 
Dry heating produced stronger deactivations compared to wet heating in the biological INP analogues, while overall being less likely to deactivate minerals. This could mean that dry heating has less potential to produce false-positive detection of biological INPs, so could be a more appropriate method for INP heat tests since wet heating is the method usually employed in these investigations. However, this may be precluded by the finding that most of our K-feldspar samples exhibited dry heat deactivations. Due to its practical simplicity and potential for high throughput of samples, heat treatments will likely continue to be the primary method used in future studies where biological INPs need to be differentiated from other types present in a collected sample. Overall, we have highlighted potential limitations and the need for deeper interpretation of results and have outlined possible improvements to INP heat treatment methods. Further studies should focus on finding the optimum physical conditions that would result in the most selective deactivations of biological INPs.

Appendix A: The effect of vessel type used for wet heating of silica INP suspensions.

In our wet heating experiments, the mineral INP suspensions were heated while inside $20 \mathrm{~mL}$ borosilicate glass vials containing $10 \mathrm{~mL}$ of suspension. Kumar et al. (2019a) observed that ageing of quartz INP suspensions over several days occurred at room 760 temperature in glass vials but not in polypropylene centrifuge tubes. For this they proposed an alternative explanation to the active sites on the quartz INP being irreversibly degraded by ageing in water, in which silicic acid leaches out from the glass vial walls and re-precipitates onto the active sites of the mineral, effectively blocking them. When polypropylene is the suspension container, however, the Si concentration remains too low for this to occur, so the INA does not reduce. Therefore, to rule out that quartz wet heat deactivations are only an artefact of heating in glass containers, we repeated our wet heat test

765 for Fluka Quartz in an alternative glass vessel type $(20 \mathrm{~mL}$ non-borosilicate vial with $10 \mathrm{~mL}$ of INP suspension) and plastic vessels $(50 \mathrm{~mL}$ propylene centrifuge tube and $1.5 \mathrm{~mL}$ polypropylene microcentrifuge tube containing $10 \mathrm{~mL}$ and $1 \mathrm{~mL}$ of INP suspension, respectively) and compared the deactivations with those seen for our standard wet heat treatment in borosilicate glass. The results in terms of $f_{\text {ice }}(T)$ are shown in Fig A1.

770 Similar or larger wet heat deactivations occurred for the $1 \mathrm{~mL}$ microcentrifuge tube $\left(\Delta T_{50}{ }^{\text {wet }}\right.$ of $\left.-6.0^{\circ} \mathrm{C}\right)$ and non-borosilicate glass vial $\left(\Delta T_{50}{ }^{\text {wet }}\right.$ of $\left.-4.8{ }^{\circ} \mathrm{C}\right)$ samples compared to that of borosilicate glass vial $\left(\Delta T_{50}{ }^{\text {wet }}\right.$ of $\left.-4.1{ }^{\circ} \mathrm{C}\right)$. With the $50 \mathrm{~mL}$ polypropylene tube sample, however, a smaller deactivation occurred: $\Delta T_{50}{ }^{\text {wet }}$ of $-1.8{ }^{\circ} \mathrm{C}$. This may simply be because the suspension in the polypropylene tube did not reach as high a temperature as that inside the glass vials while immersed in the water bath, as demonstrated in Fig. A2 based on temperature measurements in both vessel types during the heat test procedure.

775 This may have been due to the thicker wall and lower thermal conductivity of the polypropylene tube compared to the glass vials and microcentrifuge tube. Nevertheless, deactivation of quartz INP was still achieved when suspension were heated within plastic tubes, suggesting that aqueous silica leached from a glass container does not play a role in the deactivation of INA. 
https://doi.org/10.5194/amt-2021-208

Preprint. Discussion started: 29 July 2021

(c) Author(s) 2021. CC BY 4.0 License.

\section{Atmospheric Measurement \\ Techniques \\ Discussions}

Fluka Quartz- effect of vessel type

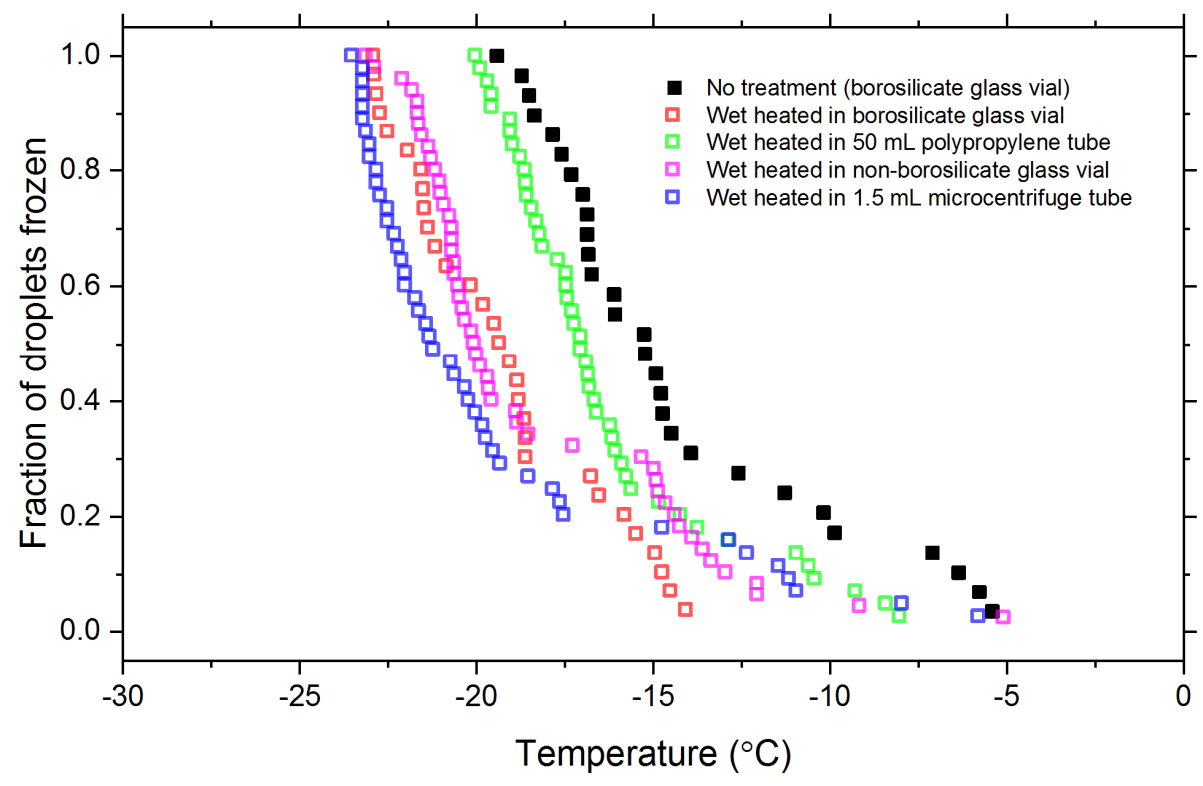

780 Figure A1: Plot showing the fraction of droplets frozen $\left(f_{\text {ice }}(T)\right)$ for wet heated Fluka Quartz suspensions (all $1 \%$ w/v) repeated using a range of different container types. 


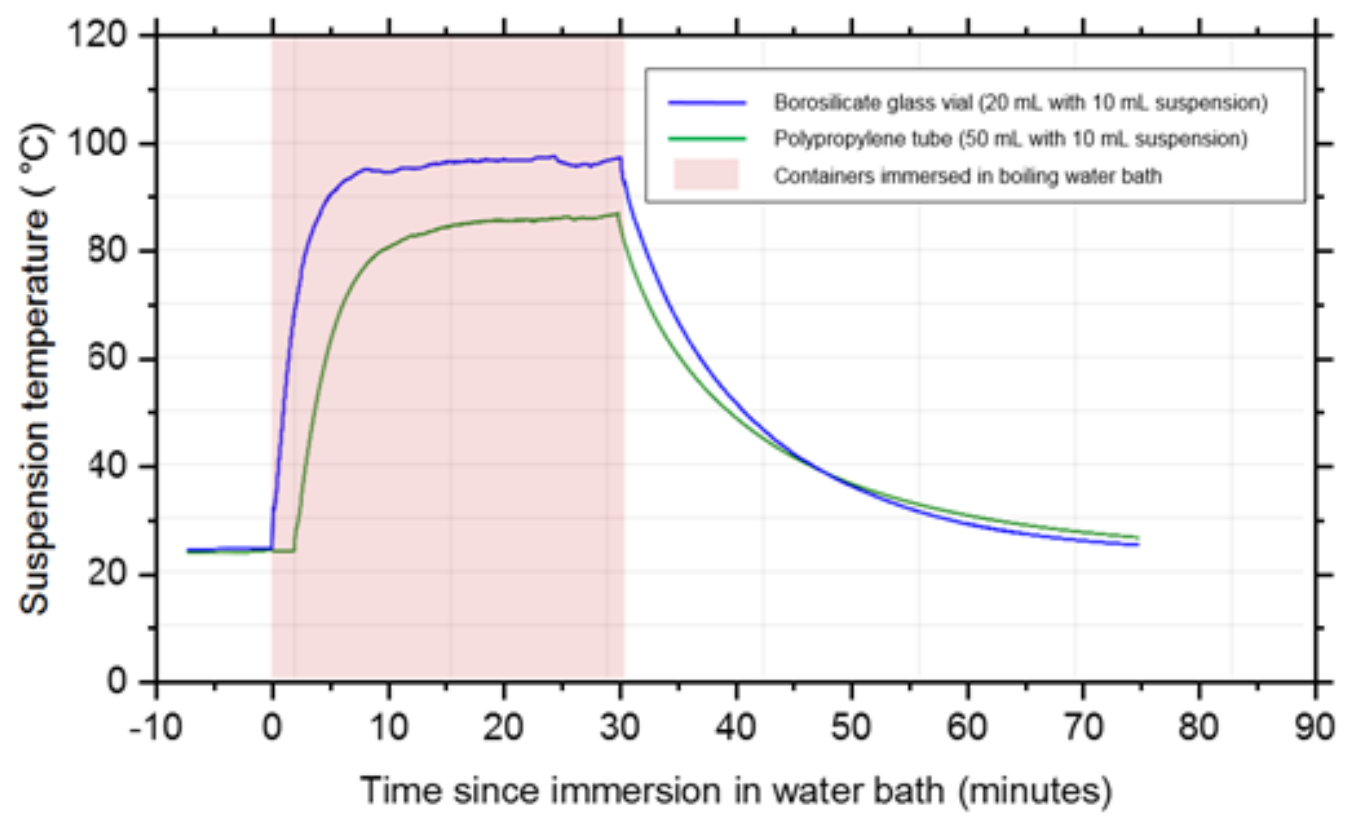

Figure A2: Thermocouple measurements of suspension temperature inside both glass and plastic vessels during the wet heat treatment procedure.

Supplement. The supplement related to this article is available online at: https://doi.org/xxx/xxx/xx-supplement.

Data availability. The dataset for this paper, including raw droplet assay freezing data, is publicly available at the University of Leeds Data Repository - https://doi.org/10.5518/1002 (Daily et al., 2021).

Author Contributions. The study was conceptualised by MID and BJM. MID designed and performed the experiments with scientific input from BJM and TFW. MID prepared the manuscript with contributions from all co-authors.

Financial support. This research has been supported by the Natural Environment Research Council (grant no. NE/L002574/1), the European Research Council (ERC, MarineIce: grant no. 648661), along with Cytiva (formerly Asymptote Ltd), Cambridge, UK. TFW thanks the Leverhulme Trust and the University of Warwick for supporting an Early Career Fellowship (ECF2018127)

Competing interests. The authors declare that they have no conflict of interest. 
Acknowledgements. The authors are grateful to Alex Harrison and Jim Atkinson who originally sourced many of the mineral samples used in this study and to Mark Holden who provided the Amazonite and Pakistan Orthoclase samples. Ulrike Proske collected and preserved the lichen sample and performed initial measurements of its INA. Andrew Hobson and Andrew Connelly provided valuable laboratory support.

\section{References}

Ansmann, A., Tesche, M., Althausen, D., Müller, D., Seifert, P., Freudenthaler, V., Heese, B., Wiegner, M., Pisani, G., Knippertz, P., and Dubovik, O.: Influence of Saharan dust on cloud glaciation in southern Morocco during the Saharan Mineral Dust Experiment, J. Geophys. Res.-Atmos., 113, https://doi.org/10.1029/2007JD008785, 2008.

Arnold, E., Merrill, J., Leinen, M., and King, J.: The effect of source area and atmospheric transport on mineral aerosol

810 collected over the North Pacific Ocean, Global. Planet. Change., 18, 137-159, https://doi.org/10.1016/S0921-8181(98)000137, 1998.

Atkinson, J. D., Murray, B. J., Woodhouse, M. T., Whale, T. F., Baustian, K. J., Carslaw, K. S., Dobbie, S., O'Sullivan, D., and Malkin, T. L.: The importance of feldspar for ice nucleation by mineral dust in mixed-phase clouds, Nature, 498, 355-358, 10.1038/nature12278, 2013.

815 Augustin-Bauditz, S., Wex, H., Kanter, S., Ebert, M., Niedermeier, D., Stolz, F., Prager, A., and Stratmann, F.: The immersion mode ice nucleation behavior of mineral dusts: A comparison of different pure and surface modified dusts, Geophys. Res. Lett., 41, 7375-7382, https://doi.org/10.1002/2014GL061317, 2014.

Augustin, S., Wex, H., Niedermeier, D., Pummer, B., Grothe, H., Hartmann, S., Tomsche, L., Clauss, T., Voigtländer, J., Ignatius, K., and Stratmann, F.: Immersion freezing of birch pollen washing water, Atmos. Chem. Phys., 13, 10989-11003, 820 10.5194/acp-13-10989-2013, 2013.

Bedjanian, Y., Romanias, M. N., and El Zein, A.: Uptake of $\mathrm{HO}_{2}$ radicals on Arizona Test Dust, Atmos. Chem. Phys., 13, 6461-6471, 10.5194/acp-13-6461-2013, 2013.

Bogler, S., and Borduas-Dedekind, N.: Lignin's ability to nucleate ice via immersion freezing and its stability towards physicochemical treatments and atmospheric processing, Atmos. Chem. Phys., 20, 14509-14522, 10.5194/acp-20-14509-2020, 2020.

Boose, Y., Baloh, P., Plötze, M., Ofner, J., Grothe, H., Sierau, B., Lohmann, U., and Kanji, Z. A.: Heterogeneous ice nucleation on dust particles sourced from nine deserts worldwide - Part 2: Deposition nucleation and condensation freezing, Atmos. Chem. Phys., 19, 1059-1076, 10.5194/acp-19-1059-2019, 2019.

Broadley, S. L., Murray, B. J., Herbert, R. J., Atkinson, J. D., Dobbie, S., Malkin, T. L., Condliffe, E., and Neve, L.: Immersion mode heterogeneous ice nucleation by an illite rich powder representative of atmospheric mineral dust, Atmos. Chem. Phys., 12, 287-307, 10.5194/acp-12-287-2012, 2012. 
https://doi.org/10.5194/amt-2021-208

Preprint. Discussion started: 29 July 2021

(c) Author(s) 2021. CC BY 4.0 License.
Atmospheric

Measurement

Techniques

Discussions

Chardon, E. S., Livens, F. R., and Vaughan, D. J.: Reactions of feldspar surfaces with aqueous solutions, Earth-Sci. Rev., 78, 1-26, https://doi.org/10.1016/j.earscirev.2006.03.002, 2006.

Cherry, M. E., and Trembath, L. T.: The disordering of alkali feldspars; I, Dry heating of a microcline perthite, Can. Mineral.,

17, 527-535, 1979.

Christner, B. C., Morris, C. E., Foreman, C. M., Cai, R., and Sands, D. C.: Ubiquity of Biological Ice Nucleators in Snowfall, Science, 319, 1214, 10.1126/science.1149757, 2008.

Conen, F., Morris, C. E., Leifeld, J., Yakutin, M. V., and Alewell, C.: Biological residues define the ice nucleation properties of soil dust, Atmos. Chem. Phys., 11, 9643-9648, 10.5194/acp-11-9643-2011, 2011.

840 Conen, F., Rodríguez, S., Hülin, C., Henne, S., Herrmann, E., Bukowiecki, N., and Alewell, C.: Atmospheric ice nuclei at the high-altitude observatory Jungfraujoch, Switzerland, Tellus. B., 67, 25014, 10.3402/tellusb.v67.25014, 2015.

Conen, F., Eckhardt, S., Gundersen, H., Stohl, A., and Yttri, K. E.: Rainfall drives atmospheric ice-nucleating particles in the coastal climate of southern Norway, Atmos. Chem. Phys., 17, 11065-11073, 10.5194/acp-17-11065-2017, 2017.

Conen, F., and Yakutin, M. V.: Soils rich in biological ice-nucleating particles abound in ice-nucleating macromolecules likely

produced by fungi, Biogeosciences, 15, 4381-4385, 10.5194/bg-15-4381-2018, 2018.

Cornwell, G. C., McCluskey, C. S., Levin, E. J. T., Suski, K. J., DeMott, P. J., Kreidenweis, S. M., and Prather, K. A.: Direct Online Mass Spectrometry Measurements of Ice Nucleating Particles at a California Coastal Site, J. Geophys. Res.-Atmos., 124, 12157-12172, https://doi.org/10.1029/2019JD030466, 2019.

Creamean, J. M., Suski, K. J., Rosenfeld, D., Cazorla, A., DeMott, P. J., Sullivan, R. C., White, A. B., Ralph, F. M., Minnis,

P., Comstock, J. M., Tomlinson, J. M., and Prather, K. A.: Dust and Biological Aerosols from the Sahara and Asia Influence Precipitation in the Western U.S, Science, 339, 1572, 10.1126/science.1227279, 2013.

Creamean, J. M., Cross, J. N., Pickart, R., McRaven, L., Lin, P., Pacini, A., Hanlon, R., Schmale, D. G., Ceniceros, J., Aydell, T., Colombi, N., Bolger, E., and DeMott, P. J.: Ice Nucleating Particles Carried From Below a Phytoplankton Bloom to the Arctic Atmosphere, Geophys. Res. Lett., 46, 8572-8581, https://doi.org/10.1029/2019GL083039, 2019.

855 Creamean, J. M., Hill, T. C. J., DeMott, P. J., Uetake, J., Kreidenweis, S., and Douglas, T. A.: Thawing permafrost: an overlooked source of seeds for Arctic cloud formation, Env. Res. Lett., 15, 084022, 10.1088/1748-9326/ab87d3, 2020.

Daily, M. I., Whale, T. F., Partanen, R., Harrison, A. D., Kilbride, P., Lamb, S., Morris, G. J., Picton, H. M., and Murray, B. J.: Cryopreservation of primary cultures of mammalian somatic cells in 96-well plates benefits from control of ice nucleation, Cryobiology, 93, 62-69, https://doi.org/10.1016/j.cryobiol.2020.02.008, 2020.

860 DeMott, P. J., Sassen, K., Poellot, M. R., Baumgardner, D., Rogers, D. C., Brooks, S. D., Prenni, A. J., and Kreidenweis, S. M.: African dust aerosols as atmospheric ice nuclei, Geophys. Res. Lett., 30, https://doi.org/10.1029/2003GL017410, 2003.

DeMott, P. J., Möhler, O., Cziczo, D. J., Hiranuma, N., Petters, M. D., Petters, S. S., Belosi, F., Bingemer, H. G., Brooks, S. D., Budke, C., Burkert-Kohn, M., Collier, K. N., Danielczok, A., Eppers, O., Felgitsch, L., Garimella, S., Grothe, H., Herenz, P., Hill, T. C. J., Höhler, K., Kanji, Z. A., Kiselev, A., Koop, T., Kristensen, T. B., Krüger, K., Kulkarni, G., Levin, E. J. T.,

Murray, B. J., Nicosia, A., O'Sullivan, D., Peckhaus, A., Polen, M. J., Price, H. C., Reicher, N., Rothenberg, D. A., Rudich, 
Y., Santachiara, G., Schiebel, T., Schrod, J., Seifried, T. M., Stratmann, F., Sullivan, R. C., Suski, K. J., Szakáll, M., Taylor, H. P., Ullrich, R., Vergara-Temprado, J., Wagner, R., Whale, T. F., Weber, D., Welti, A., Wilson, T. W., Wolf, M. J., and Zenker, J.: The Fifth International Workshop on Ice Nucleation phase 2 (FIN-02): laboratory intercomparison of ice nucleation measurements, Atmos. Meas. Tech., 11, 6231-6257, 10.5194/amt-11-6231-2018, 2018.

Dreischmeier, K., Budke, C., Wiehemeier, L., Kottke, T., and Koop, T.: Boreal pollen contain ice-nucleating as well as icebinding 'antifreeze' polysaccharides, Sci Rep, 7, 41890, 10.1038/srep41890, 2017.

Field, P. R., Lawson, R. P., Brown, P. R. A., Lloyd, G., Westbrook, C., Moisseev, D., Miltenberger, A., Nenes, A., Blyth, A., Choularton, T., Connolly, P., Buehl, J., Crosier, J., Cui, Z., Dearden, C., DeMott, P., Flossmann, A., Heymsfield, A., Huang, Y., Kalesse, H., Kanji, Z. A., Korolev, A., Kirchgaessner, A., Lasher-Trapp, S., Leisner, T., McFarquhar, G., Phillips, V., Stith, 875 J., and Sullivan, S.: Secondary Ice Production: Current State of the Science and Recommendations for the Future, Meteor. Mon., 58, 7.1-7.20, 10.1175/AMSMONOGRAPHS-D-16-0014.1, 2017.

Fröhlich-Nowoisky, J., Hill, T. C. J., Pummer, B. G., Yordanova, P., Franc, G. D., and Pöschl, U.: Ice nucleation activity in the widespread soil fungus Mortierella alpina, Biogeosciences, 12, 1057-1071, 10.5194/bg-12-1057-2015, 2015.

Garcia, E., Hill, T. C. J., Prenni, A. J., DeMott, P. J., Franc, G. D., and Kreidenweis, S. M.: Biogenic ice nuclei in boundary 880 layer air over two U.S. High Plains agricultural regions, J. Geophys. Res.-Atmos., 117, n/a-n/a, 10.1029/2012jd018343, 2012. Glaccum, R. A., and Prospero, J. M.: Saharan aerosols over the tropical North Atlantic - Mineralogy, Mar. Geol., 37, 295321, https://doi.org/10.1016/0025-3227(80)90107-3, 1980.

Grawe, S., Augustin-Bauditz, S., Clemen, H. C., Ebert, M., Eriksen Hammer, S., Lubitz, J., Reicher, N., Rudich, Y., Schneider, J., Staacke, R., Stratmann, F., Welti, A., and Wex, H.: Coal fly ash: linking immersion freezing behavior and physicochemical 885 particle properties, Atmos. Chem. Phys., 18, 13903-13923, 10.5194/acp-18-13903-2018, 2018.

Hara, K., Maki, T., Kakikawa, M., Kobayashi, F., and Matsuki, A.: Effects of different temperature treatments on biological ice nuclei in snow samples, Atmos. Env., 140, 415-419, 10.1016/j.atmosenv.2016.06.011, 2016.

Harrison, A. D., Whale, T. F., Carpenter, M. A., Holden, M. A., Neve, L., amp, apos, Sullivan, D., Vergara Temprado, J., and Murray, B. J.: Not all feldspars are equal: a survey of ice nucleating properties across the feldspar group of minerals, Atmos. Chem. Phys., 16, 10927-10940, 10.5194/acp-16-10927-2016, 2016.

Harrison, A. D., Lever, K., Sanchez-Marroquin, A., Holden, M. A., Whale, T. F., Tarn, M. D., McQuaid, J. B., and Murray, B. J.: The ice-nucleating ability of quartz immersed in water and its atmospheric importance compared to K-feldspar, Atmos. Chem. Phys., 19, 11343-11361, 10.5194/acp-19-11343-2019, 2019.

Hartmann, M., Adachi, K., Eppers, O., Haas, C., Herber, A., Holzinger, R., Hünerbein, A., Jäkel, E., Jentzsch, C., van 895 Pinxteren, M., Wex, H., Willmes, S., and Stratmann, F.: Wintertime Airborne Measurements of Ice Nucleating Particles in the High Arctic: A Hint to a Marine, Biogenic Source for Ice Nucleating Particles, Geophys. Res. Lett., 47, e2020GL087770, https://doi.org/10.1029/2020GL087770, 2020. 
https://doi.org/10.5194/amt-2021-208

Preprint. Discussion started: 29 July 2021

(c) Author(s) 2021. CC BY 4.0 License.
Atmospheric

Measurement

Techniques

Discussions

Hawker, R. E., Miltenberger, A. K., Wilkinson, J. M., Hill, A. A., Shipway, B. J., Cui, Z., Cotton, R. J., Carslaw, K. S., Field, P. R., and Murray, B. J.: The temperature dependence of ice-nucleating particle concentrations affects the radiative properties of tropical convective cloud systems, Atmos. Chem. Phys., 21, 5439-5461, 10.5194/acp-21-5439-2021, 2021.

Henderson-Begg, S. K., Hill, T., Thyrhaug, R., Khan, M., and Moffett, B. F.: Terrestrial and airborne non-bacterial ice nuclei, Atmos. Sci. Lett., 10, 215-219, https://doi.org/10.1002/asl.241, 2009.

Herbert, R. J., Murray, B. J., Whale, T. F., Dobbie, S. J., and Atkinson, J. D.: Representing time-dependent freezing behaviour in immersion mode ice nucleation, Atmos. Chem. Phys., 14, 8501-8520, 10.5194/acp-14-8501-2014, 2014.

Herbert, R. J., Murray, B. J., Dobbie, S. J., and Koop, T.: Sensitivity of liquid clouds to homogenous freezing parameterizations, Geophys. Res. Lett., 42, 1599-1605, https://doi.org/10.1002/2014GL062729, 2015.

Hill, T. C. J., Moffett, B. F., Demott, P. J., Georgakopoulos, D. G., Stump, W. L., and Franc, G. D.: Measurement of ice nucleation-active bacteria on plants and in precipitation by quantitative PCR, Appl Environ Microbiol, 80, 1256-1267, 10.1128/AEM.02967-13, 2014.

Hill, T. C. J., DeMott, P. J., Tobo, Y., Fröhlich-Nowoisky, J., Moffett, B. F., Franc, G. D., and Kreidenweis, S. M.: Sources of organic ice nucleating particles in soils, Atmos. Chem. Phys., 16, 7195-7211, 10.5194/acp-16-7195-2016, 2016.

Hiranuma, N., Hoffmann, N., Kiselev, A., Dreyer, A., Zhang, K., Kulkarni, G., Koop, T., and Möhler, O.: Influence of surface morphology on the immersion mode ice nucleation efficiency of hematite particles, Atmos. Chem. Phys., 14, 2315-2324, 10.5194/acp-14-2315-2014, 2014.

915 Hiranuma, N., Augustin-Bauditz, S., Bingemer, H., Budke, C., Curtius, J., Danielczok, A., Diehl, K., Dreischmeier, K., Ebert, M., Frank, F., Hoffmann, N., Kandler, K., Kiselev, A., Koop, T., Leisner, T., Möhler, O., Nillius, B., Peckhaus, A., Rose, D., Weinbruch, S., Wex, H., Boose, Y., DeMott, P. J., Hader, J. D., Hill, T. C. J., Kanji, Z. A., Kulkarni, G., Levin, E. J. T., McCluskey, C. S., Murakami, M., Murray, B. J., Niedermeier, D., Petters, M. D., O'Sullivan, D., Saito, A., Schill, G. P., Tajiri, T., Tolbert, M. A., Welti, A., Whale, T. F., Wright, T. P., and Yamashita, K.: A comprehensive laboratory study on the immersion freezing behavior of illite NX particles: a comparison of 17 ice nucleation measurement techniques, Atmos. Chem. Phys., 15, 2489-2518, 10.5194/acp-15-2489-2015, 2015a.

Hiranuma, N., Möhler, O., Yamashita, K., Tajiri, T., Saito, A., Kiselev, A., Hoffmann, N., Hoose, C., Jantsch, E., Koop, T., and Murakami, M.: Ice nucleation by cellulose and its potential contribution to ice formation in clouds, Nat. Geosci., 8, 273277, 10.1038/ngeo2374, 2015b.

925 Hiranuma, N., Adachi, K., Bell, D. M., Belosi, F., Beydoun, H., Bhaduri, B., Bingemer, H., Budke, C., Clemen, H. C., Conen, F., Cory, K. M., Curtius, J., DeMott, P. J., Eppers, O., Grawe, S., Hartmann, S., Hoffmann, N., Höhler, K., Jantsch, E., Kiselev, A., Koop, T., Kulkarni, G., Mayer, A., Murakami, M., Murray, B. J., Nicosia, A., Petters, M. D., Piazza, M., Polen, M., Reicher, N., Rudich, Y., Saito, A., Santachiara, G., Schiebel, T., Schill, G. P., Schneider, J., Segev, L., Stopelli, E., Sullivan, R. C., Suski, K., Szakáll, M., Tajiri, T., Taylor, H., Tobo, Y., Ullrich, R., Weber, D., Wex, H., Whale, T. F., Whiteside, C. L., 930 Yamashita, K., Zelenyuk, A., and Möhler, O.: A comprehensive characterization of ice nucleation by three different types of cellulose particles immersed in water, Atmos. Chem. Phys., 19, 4823-4849, 10.5194/acp-19-4823-2019, 2019. 
Hofmeister, A. M., and Rossman, G. R.: A model for the irradiative coloration of smoky feldspar and the inhibiting influence of water, Phys. Chem. Miner., 12, 324-332, 10.1007/BF00654342, 1985.

Holden, M. A., Whale, T. F., Tarn, M. D., O'Sullivan, D., Walshaw, R. D., Murray, B. J., Meldrum, F. C., and Christenson, H.

935 K.: High-speed imaging of ice nucleation in water proves the existence of active sites, Sci Adv, 5, eaav4316, 10.1126/sciadv.aav4316, 2019.

Holden, M. A., Campbell, J. M., Meldrum, F. C., Murray, B. J., and Christenson, H. K.: Active sites for ice nucleation differ depending on nucleation mode, P. Nat. Acad. Sci. USA., 118, e2022859118, 10.1073/pnas.2022859118, 2021.

Hoose, C., Kristjánsson, J. E., and Burrows, S. M.: How important is biological ice nucleation in clouds on a global scale?,

940 Environ. Res. Lett., 5, 024009, 10.1088/1748-9326/5/2/024009, 2010.

Hoose, C., and Möhler, O.: Heterogeneous ice nucleation on atmospheric aerosols: a review of results from laboratory experiments, Atmos. Chem. Phys., 12, 9817-9854, 10.5194/acp-12-9817-2012, 2012.

Huang, S., Hu, W., Chen, J., Wu, Z., Zhang, D., and Fu, P.: Overview of biological ice nucleating particles in the atmosphere, Environ. Int., 146, 106197, https://doi.org/10.1016/j.envint.2020.106197, 2021.

945 Huffman, J. A., Prenni, A. J., DeMott, P. J., Pöhlker, C., Mason, R. H., Robinson, N. H., Fröhlich-Nowoisky, J., Tobo, Y., Després, V. R., Garcia, E., Gochis, D. J., Harris, E., Müller-Germann, I., Ruzene, C., Schmer, B., Sinha, B., Day, D. A., Andreae, M. O., Jimenez, J. L., Gallagher, M., Kreidenweis, S. M., Bertram, A. K., and Pöschl, U.: High concentrations of biological aerosol particles and ice nuclei during and after rain, Atmos. Chem. Phys., 13, 6151-6164, 10.5194/acp-13-61512013, 2013.

Ickes, L., Welti, A., Hoose, C., and Lohmann, U.: Classical nucleation theory of homogeneous freezing of water: thermodynamic and kinetic parameters, Phys Chem Chem Phys, 17, 5514-5537, 10.1039/c4cp04184d, 2015.

Johnson, E. A., and Rossman, G. R.: The concentration and speciation of hydrogen in feldspars using FTIR and 1H MAS NMR spectroscopy, Am. Mineral., 88, 901-911, 10.2138/am-2003-5-620, 2003.

Johnson, E. A., and Rossman, G. R.: A survey of hydrous species and concentrations in igneous feldspars, American

955 Mineralogist, 89, 586-600, doi:10.2138/am-2004-0413, 2004.

Joly, M., Amato, P., Deguillaume, L., Monier, M., Hoose, C., and Delort, A. M.: Quantification of ice nuclei active at near 0 ${ }^{\circ} \mathrm{C}$ temperatures in low-altitude clouds at the Puy de Dôme atmospheric station, Atmos. Chem. Phys., 14, 8185-8195, 10.5194/acp-14-8185-2014, 2014.

Joyce, R. E., Lavender, H., Farrar, J., Werth, J. T., Weber, C. F., D’Andrilli, J., Vaitilingom, M., and Christner, B. C.: 960 Biological Ice-Nucleating Particles Deposited Year-Round in Subtropical Precipitation, Appl Environ Microbiol, 85, e0156701519, 10.1128/AEM.01567-19, 2019.

Kandler, K., SchüTz, L., Deutscher, C., Ebert, M., Hofmann, H., JäCkel, S., Jaenicke, R., Knippertz, P., Lieke, K., Massling, A., Petzold, A., Schladitz, A., Weinzierl, B., Wiedensohler, A., Zorn, S., and Weinbruch, S.: Size distribution, mass concentration, chemical and mineralogical composition and derived optical parameters of the boundary layer aerosol at Tinfou, 
Morocco, during SAMUM 2006, Tellus B: Chemical and Physical Meteorology, 61, 32-50, 10.1111/j.16000889.2008.00385.x, 2009.

Kanji, Z. A., Ladino, L. A., Wex, H., Boose, Y., Burkert-Kohn, M., Cziczo, D. J., and Krämer, M.: Overview of Ice Nucleating Particles, Meteorol. Monogr., 58, 1.1-1.33, 10.1175/amsmonographs-d-16-0006.1, 2017.

Kaufmann, L., Marcolli, C., Hofer, J., Pinti, V., Hoyle, C. R., and Peter, T.: Ice nucleation efficiency of natural dust samples in the immersion mode, Atmos. Chem. Phys., 16, 11177-11206, 10.5194/acp-16-11177-2016, 2016.

Kieft, T. L., and Ruscetti, T.: Characterization of biological ice nuclei from a lichen, J Bacteriol, 172, 3519-3523, 10.1128/jb.172.6.3519-3523.1990, 1990.

Kiselev, A., Bachmann, F., Pedevilla, P., Cox, S. J., Michaelides, A., Gerthsen, D., and Leisner, T.: Active sites in heterogeneous ice nucleation-the example of K-rich feldspars, Science, 355, 367-371, 10.1126/science.aai8034, 2017.

975 Kiselev, A., Keinert, A., Gaedecke, T., Leisner, T., Sutter, C., Petrishcheva, E., and Abart, R.: Effect of chemically induced fracturing on the ice nucleation activity of alkali feldspar, Atmos. Chem. Phys. Discuss., 2021, 1-17, 10.5194/acp-2021-18, 2021.

Knackstedt, K. A., Moffett, B. F., Hartmann, S., Wex, H., Hill, T. C. J., Glasgo, E. D., Reitz, L. A., Augustin-Bauditz, S., Beall, B. F. N., Bullerjahn, G. S., Fröhlich-Nowoisky, J., Grawe, S., Lubitz, J., Stratmann, F., and McKay, R. M. L.: Terrestrial 980 Origin for Abundant Riverine Nanoscale Ice-Nucleating Particles, Environ. Sci. Technol., 52, 12358-12367, 10.1021/acs.est.8b03881, 2018.

Knippertz, P., and Stuut, J.: Mineral Dust: A Key Player in the Earth System, Mineral Dust, 2014.

Koop, T., and Zobrist, B.: Parameterizations for ice nucleation in biological and atmospheric systems, Phys Chem Chem Phys, 11, 10839-10850, 10.1039/b914289d, 2009.

985 Kulkarni, G., Zhang, K., Zhao, C., Nandasiri, M., Shutthanandan, V., Liu, X., Fast, J., and Berg, L.: Ice formation on nitric acid-coated dust particles: Laboratory and modeling studies, J. Geophys. Res.-Atmos., 120, 7682-7698, https://doi.org/10.1002/2014JD022637, 2015.

Kumar, A., Marcolli, C., Luo, B., and Peter, T.: Ice nucleation activity of silicates and aluminosilicates in pure water and aqueous solutions - Part 1: The K-feldspar microcline, Atmos. Chem. Phys., 18, 7057-7079, 10.5194/acp-18-7057-2018, 990 2018a.

Kumar, A., Marcolli, C., and Peter, T.: Ice nucleation activity of silicates and aluminosilicates in pure water and aqueous solutions. Part 2 \&amp;ndash; Quartz and amorphous silica, Atmos. Chem. Phys. Discussions, 1-35, 10.5194/acp-2018-1020, 2018b.

Kumar, A., Marcolli, C., and Peter, T.: Ice nucleation activity of silicates and aluminosilicates in pure water and aqueous 995 solutions - Part 2: Quartz and amorphous silica, Atmos. Chem. Phys., 19, 6035-6058, 10.5194/acp-19-6035-2019, 2019a.

Kumar, A., Marcolli, C., and Peter, T.: Ice nucleation activity of silicates and aluminosilicates in pure water and aqueous solutions - Part 3: Aluminosilicates, Atmos. Chem. Phys., 19, 6059-6084, 10.5194/acp-19-6059-2019, 2019 b. 
Kunert, A. T., Lamneck, M., Helleis, F., Pöschl, U., Pöhlker, M. L., and Fröhlich-Nowoisky, J.: Twin-plate Ice Nucleation Assay (TINA) with infrared detection for high-throughput droplet freezing experiments with biological ice nuclei in laboratory and field samples, Atmos. Meas. Tech., 11, 6327-6337, 10.5194/amt-11-6327-2018, 2018.

Lee, M. R., Hodson, M. E., Brown, D. J., MacKenzie, M., and Smith, C. L.: The composition and crystallinity of the nearsurface regions of weathered alkali feldspars, Geochimica et Cosmochimica Acta, 72, 4962-4975, https://doi.org/10.1016/j.gca.2008.08.001, 2008.

Liu, W. D., Yang, Y., Zhu, K. Y., and Xia, Q. K.: Temperature dependences of hydrous species in feldspars, Physics and Chemistry of Minerals, 45, 609-620, 10.1007/s00269-018-0946-1, 2018.

Lundheim, R.: Physiological and ecological significance of biological ice nucleators, Philos Trans R Soc Lond B Biol Sci, 357, 937-943, 10.1098/rstb.2002.1082, 2002.

Marcolli, C., Gedamke, S., Peter, T., and Zobrist, B.: Efficiency of immersion mode ice nucleation on surrogates of mineral dust, Atmos. Chem. Phys., 7, 5081-5091, 10.5194/acp-7-5081-2007, 2007.

1010 Mason, B. J., and Maybank, J.: Ice-nucleating properties of some natural mineral dusts, Q. J. R. Meteorol. Soc., 84, 235-241, https://doi.org/10.1002/qj.49708436104, 1958.

Maters, E. C., Cimarelli, C., Casas, A. S., Dingwell, D. B., and Murray, B. J.: Volcanic ash ice-nucleating activity can be enhanced or depressed by ash-gas interaction in the eruption plume, Earth. Planet. Sc. Lett., 551, 116587, https://doi.org/10.1016/j.epsl.2020.116587, 2020.

1015 McCluskey, C. S., Hill, T. C. J., Sultana, C. M., Laskina, O., Trueblood, J., Santander, M. V., Beall, C. M., Michaud, J. M., Kreidenweis, S. M., Prather, K. A., Grassian, V., and DeMott, P. J.: A Mesocosm Double Feature: Insights into the Chemical Makeup of Marine Ice Nucleating Particles, J. Atmos. Sci., 75, 2405-2423, 10.1175/JAS-D-17-0155.1, 2018.

Michaud, A. B., Dore, J. E., Leslie, D., Lyons, W. B., Sands, D. C., and Priscu, J. C.: Biological ice nucleation initiates hailstone formation, J. Geophys. Res.-Atmos., 119, 12,186-112,197, https://doi.org/10.1002/2014JD022004, 2014.

1020 Moffett, B. F., Getti, G., Henderson-Begg, S. K., and Hill, T. C. J.: Ubiquity of ice nucleation in lichen — possible atmospheric implications, Lindbergia, 38, 39-43, 10.25227/linbg.01070, 2015.

Moffett, B. F., Hill, T. C. J., and DeMott, P. J.: Abundance of Biological Ice Nucleating Particles in the Mississippi and Its Major Tributaries, Atmosphere, 9, 10.3390/atmos9080307, 2018.

Morris, C. E., Conen, F., Alex Huffman, J., Phillips, V., Pöschl, U., and Sands, D. C.: Bioprecipitation: a feedback cycle linking Earth history, ecosystem dynamics and land use through biological ice nucleators in the atmosphere, Global Change Biology, 20, 341-351, https://doi.org/10.1111/gcb.12447, 2014.

Morris, G. J., and Lamb, S.: Improved Methods for Cryopreservation of Biological Materal, U.S. Patent Application \# 15/557320, 2018.

Murray, B. J., O'Sullivan, D., Atkinson, J. D., and Webb, M. E.: Ice nucleation by particles immersed in supercooled cloud droplets, Chem Soc Rev, 41, 6519-6554, 10.1039/c2cs35200a, 2012. 
Murray, B. J., Carslaw, K. S., and Field, P. R.: Opinion: Cloud-phase climate feedback and the importance of ice-nucleating particles, Atmos. Chem. Phys., 21, 665-679, 10.5194/acp-21-665-2021, 2021.

Niemand, M., Möhler, O., Vogel, B., Vogel, H., Hoose, C., Connolly, P., Klein, H., Bingemer, H., DeMott, P., Skrotzki, J., and Leisner, T.: A Particle-Surface-Area-Based Parameterization of Immersion Freezing on Desert Dust Particles, J. Atmos. Sci., 69, 3077-3092, 10.1175/jas-d-11-0249.1, 2012.

O'Sullivan, D., Murray, B. J., Malkin, T. L., Whale, T. F., Umo, N. S., Atkinson, J. D., Price, H. C., Baustian, K. J., Browse, J., and Webb, M. E.: Ice nucleation by fertile soil dusts: relative importance of mineral and biogenic components, Atmos. Chem. Phys., 14, 1853-1867, 10.5194/acp-14-1853-2014, 2014.

O'Sullivan, D., Murray, B. J., Ross, J. F., and Webb, M. E.: The adsorption of fungal ice-nucleating proteins on mineral dusts:

1040 a terrestrial reservoir of atmospheric ice-nucleating particles, Atmos. Chem. Phys., 16, 7879-7887, 10.5194/acp-16-7879-2016, 2016.

O'Sullivan, D., Murray, B. J., Ross, J. F., Whale, T. F., Price, H. C., Atkinson, J. D., Umo, N. S., and Webb, M. E.: The relevance of nanoscale biological fragments for ice nucleation in clouds, Scientific Reports, 5, 8082, 10.1038/srep08082

Obata, H., Nakai, T., Tanishita, J., and Tokuyama, T.: Identification of an ice-nucleating bacterium and its ice nucleation

1045 properties, J.Ferment. Bioeng., 67, 143-147, https://doi.org/10.1016/0922-338X(89)90111-6, 1989.

Paramonov, M., David, R. O., Kretzschmar, R., and Kanji, Z. A.: A laboratory investigation of the ice nucleation efficiency of three types of mineral and soil dust, Atmos. Chem. Phys., 18, 16515-16536, 10.5194/acp-18-16515-2018, 2018.

Parsons, I., Fitz Gerald, J. D., and Lee, M. R.: Routine characterization and interpretation of complex alkali feldspar intergrowths, Am. Mineral., 100, 1277-1303, 10.2138/am-2015-5094, 2015.

1050 eckhaus, A., Kiselev, A., Hiron, T., Ebert, M., and Leisner, T.: A comparative study of K-rich and Na/Ca-rich feldspar icenucleating particles in a nanoliter droplet freezing assay, Atmos. Chem. Phys., 16, 11477-11496, 10.5194/acp-16-11477-2016, 2016.

Pedevilla, P., Fitzner, M., and Michaelides, A.: What makes a good descriptor for heterogeneous ice nucleation on OHpatterned surfaces, Phys. Rev. B, 96, 10.1103/PhysRevB.96.115441, 2017.

1055 Perkins, R. J., Gillette, S. M., Hill, T. C. J., and DeMott, P. J.: The Labile Nature of Ice Nucleation by Arizona Test Dust, ACS. Earth. Space. Chem., 4, 133-141, 10.1021/acsearthspacechem.9b00304, 2020.

Pietsch, R. B., Vinatzer, B. A., and Schmale, D. G.: Diversity and Abundance of Ice Nucleating Strains of Pseudomonas syringae in a Freshwater Lake in Virginia, USA, Front. Microbiol., 8, 318, 2017.

Polen, M., Lawlis, E., and Sullivan, R. C.: The unstable ice nucleation properties of Snomax ${ }^{\circledR}$ bacterial particles, J. Geophys.

1060 Res.-Atmos., 121, 11,666-611,678, https://doi.org/10.1002/2016JD025251, 2016.

Pouleur, S., Richard, C., Martin, J. G., and Antoun, H.: Ice Nucleation Activity in Fusarium acuminatum and Fusarium avenaceum, Appl Environ Microbiol, 58, 2960-2964, 10.1128/AEM.58.9.2960-2964.1992, 1992.

Pratt, K. A., DeMott, P. J., French, J. R., Wang, Z., Westphal, D. L., Heymsfield, A. J., Twohy, C. H., Prenni, A. J., and Prather, K. A.: In situ detection of biological particles in cloud ice-crystals, Nat. Geosci., 2, 398-401, 10.1038/ngeo521, 2009. 
1065 Pruppacher, H. R.: Microphysics of clouds and precipitation / by Hans R. Pruppacher and James D. Klett, Accessed from https://nla.gov.au/nla.cat-vn946461, edited by: Klett, J. D., D. Reidel Pub. Co, Dordrecht, Holland ; Boston, 1978.

Pummer, B. G., Bauer, H., Bernardi, J., Bleicher, S., and Grothe, H.: Suspendable macromolecules are responsible for ice nucleation activity of birch and conifer pollen, Atmos. Chem. Phys., 12, 2541-2550, 10.5194/acp-12-2541-2012, 2012.

Pummer, B. G., Budke, C., Augustin-Bauditz, S., Niedermeier, D., Felgitsch, L., Kampf, C. J., Huber, R. G., Liedl, K. R., Loerting, T., Moschen, T., Schauperl, M., Tollinger, M., Morris, C. E., Wex, H., Grothe, H., Pöschl, U., Koop, T., and FröhlichNowoisky, J.: Ice nucleation by water-soluble macromolecules, Atmos. Chem. Phys., 15, 4077-4091, 10.5194/acp-15-40772015, 2015.

Rosenfeld, D., Yu, X., Liu, G., Xu, X., Zhu, Y., Yue, Z., Dai, J., Dong, Z., Dong, Y., and Peng, Y.: Glaciation temperatures of convective clouds ingesting desert dust, air pollution and smoke from forest fires, Geophys. Res. Lett., 38, https://doi.org/10.1029/2011GL049423, 2011.

Roy, P., House, M. L., and Dutcher, C. S.: A Microfluidic Device for Automated High Throughput Detection of Ice Nucleation of Snomax®, Micromachines, 12, 10.3390/mi12030296, 2021.

Sanchez-Marroquin, A., West, J. S., Burke, I. T., McQuaid, J. B., and Murray, B. J.: Mineral and biological ice-nucleating particles above the South East of the British Isles, Environ. Sci.: Atmos., 1, 176-191, 10.1039/D1EA00003A, 2021.

1080 Šantl-Temkiv, T., Lange, R., Beddows, D., Rauter, U., Pilgaard, S., Dall'Osto, M., Gunde-Cimerman, N., Massling, A., and Wex, H.: Biogenic Sources of Ice Nucleating Particles at the High Arctic Site Villum Research Station, Environ. Sci. Technol., 53, 10580-10590, 10.1021/acs.est.9b00991, 2019.

Schneider, J., Höhler, K., Heikkilä, P., Keskinen, J., Bertozzi, B., Bogert, P., Schorr, T., Umo, N. S., Vogel, F., Brasseur, Z., Wu, Y., Hakala, S., Duplissy, J., Moisseev, D., Kulmala, M., Adams, M. P., Murray, B. J., Korhonen, K., Hao, L., Thomson,

1085 E. S., Castarède, D., Leisner, T., Petäjä, T., and Möhler, O.: The seasonal cycle of ice-nucleating particles linked to the abundance of biogenic aerosol in boreal forests, Atmos. Chem. Phys. Discuss., 2020, 1-18, 10.5194/acp-2020-683, 2020.

Schnell, R. C., and Vali, G.: Biogenic Ice Nuclei: Part I. Terrestrial and Marine Sources, J. Atmos. Sci., 33, 1554-1564, 10.1175/1520-0469(1976)033<1554:BINPIT>2.0.CO;2, 1976.

Storelvmo, T., and Tan, I.: The Wegener-Bergeron-Findeisen process - Its discovery and vital importance for weather and 1090 climate, Meteorol. Z., 24, 455-461, 2015.

Sullivan, R. C., Petters, M. D., DeMott, P. J., Kreidenweis, S. M., Wex, H., Niedermeier, D., Hartmann, S., Clauss, T., Stratmann, F., Reitz, P., Schneider, J., and Sierau, B.: Irreversible loss of ice nucleation active sites in mineral dust particles caused by sulphuric acid condensation, Atmos. Chem. Phys., 10, 11471-11487, 10.5194/acp-10-11471-2010, 2010.

Suski, K. J., Hill, T. C. J., Levin, E. J. T., Miller, A., DeMott, P. J., and Kreidenweis, S. M.: Agricultural harvesting emissions 1095 of ice nucleating particles, Atmos. Chem. Phys. Discussions, 1-30, 10.5194/acp-2018-348, 2018.

Tarn, M. D., Sikora, S. N. F., Porter, G. C. E., O’Sullivan, D., Adams, M., Whale, T. F., Harrison, A. D., Vergara-Temprado, J., Wilson, T. W., Shim, J.-u., and Murray, B. J.: The study of atmospheric ice-nucleating particles via microfluidically generated droplets, Microfluid. Nanofluid., 22, 52, 10.1007/s10404-018-2069-x, 2018. 
Tarn, M. D., Sikora, S. N. F., Porter, G. C. E., Wyld, B. V., Alayof, M., Reicher, N., Harrison, A. D., Rudich, Y., Shim, J.-u., and Murray, B. J.: On-chip analysis of atmospheric ice-nucleating particles in continuous flow, Lab. Chip., 20, 2889-2910, 10.1039/D0LC00251H, 2020.

Tobo, Y., DeMott, P. J., Hill, T. C. J., Prenni, A. J., Swoboda-Colberg, N. G., Franc, G. D., and Kreidenweis, S. M.: Organic matter matters for ice nuclei of agricultural soil origin, Atmos. Chem. Phys., 14, 8521-8531, 10.5194/acp-14-8521-2014, 2014. Tobo, Y., Adachi, K., DeMott, P. J., Hill, T. C. J., Hamilton, D. S., Mahowald, N. M., Nagatsuka, N., Ohata, S., Uetake, J.,

1105 Kondo, Y., and Koike, M.: Glacially sourced dust as a potentially significant source of ice nucleating particles, Nat. Geosci., 12, 253-258, 10.1038/s41561-019-0314-x, 2019.

Ullrich, R., Hoose, C., Möhler, O., Niemand, M., Wagner, R., Höhler, K., Hiranuma, N., Saathoff, H., and Leisner, T.: A New Ice Nucleation Active Site Parameterization for Desert Dust and Soot, J. Atmos. Sci., 74, 699-717, 10.1175/jas-d-16-0074.1, 2017.

1110 Vali, G.: Quantitative Evaluation of Experimental Results an the Heterogeneous Freezing Nucleation of Supercooled Liquids, J.Atmos. Sci., 28, 402-409, 10.1175/1520-0469(1971)028<0402:QEOERA>2.0.CO;2, 1971.

Vali, G.: Freezing Rate Due to Heterogeneous Nucleation, J.Atmos. Sci., 51, 1843-1856, 10.1175/15200469(1994)051<1843:FRDTHN>2.0.CO;2, 1994.

Vergara-Temprado, J., Murray, B. J., Wilson, T. W., amp, apos, Sullivan, D., Browse, J., Pringle, K. J., Ardon-Dryer, K.,

1115 Bertram, A. K., Burrows, S. M., Ceburnis, D., DeMott, P. J., Mason, R. H., amp, apos, Dowd, C. D., Rinaldi, M., and Carslaw, K. S.: Contribution of feldspar and marine organic aerosols to global ice nucleating particle concentrations, Atmos. Chem. Phys., 17, 3637-3658, 10.5194/acp-17-3637-2017, 2017.

Vergara-Temprado, J., Miltenberger, A. K., Furtado, K., Grosvenor, D. P., Shipway, B. J., Hill, A. A., Wilkinson, J. M., Field, P. R., Murray, B. J., and Carslaw, K. S.: Strong control of Southern Ocean cloud reflectivity by ice-nucleating particles, Proc 1120 Natl Acad Sci U S A, 115, 2687-2692, 10.1073/pnas.1721627115, 2018.

Warren, G. J.: Bacterial Ice Nucleation: Molecular Biology and Applications, Biotechnology and Genetic Engineering Reviews, 5, 107-136, 10.1080/02648725.1987.10647836, 1987.

Welti, A., Lohmann, U., and Kanji, Z. A.: Ice nucleation properties of K-feldspar polymorphs and plagioclase feldspars, Atmos. Chem. Phys. Discussions, 1-25, 10.5194/acp-2018-1271, 2019.

1125 Wex, H., Augustin-Bauditz, S., Boose, Y., Budke, C., Curtius, J., Diehl, K., Dreyer, A., Frank, F., Hartmann, S., Hiranuma, N., Jantsch, E., Kanji, Z. A., Kiselev, A., Koop, T., Möhler, O., Niedermeier, D., Nillius, B., Rösch, M., Rose, D., Schmidt, C., Steinke, I., and Stratmann, F.: Intercomparing different devices for the investigation of ice nucleating particles using Snomax $<$ sup $>{ }^{\circledR}</$ sup $>$ as test substance, Atmos. Chem. Phys., 15, 1463-1485, 10.5194/acp-15-1463-2015, 2015.

Whale, T. F., Murray, B. J., O'Sullivan, D., Wilson, T. W., Umo, N. S., Baustian, K. J., Atkinson, J. D., Workneh, D. A., and 1130 Morris, G. J.: A technique for quantifying heterogeneous ice nucleation in microlitre supercooled water droplets, Atmos. Meas. Tech., 8, 2437-2447, 10.5194/amt-8-2437-2015, 2015. 
Whale, T. F., Holden, M. A., Kulak, A. N., Kim, Y. Y., Meldrum, F. C., Christenson, H. K., and Murray, B. J.: The role of phase separation and related topography in the exceptional ice-nucleating ability of alkali feldspars, Phys Chem Chem Phys, 19, 31186-31193, 10.1039/c7cp04898j, 2017.

1135 Wilson, T. W., Ladino, L. A., Alpert, P. A., Breckels, M. N., Brooks, I. M., Browse, J., Burrows, S. M., Carslaw, K. S., Huffman, J. A., Judd, C., Kilthau, W. P., Mason, R. H., McFiggans, G., Miller, L. A., Najera, J. J., Polishchuk, E., Rae, S., Schiller, C. L., Si, M., Temprado, J. V., Whale, T. F., Wong, J. P., Wurl, O., Yakobi-Hancock, J. D., Abbatt, J. P., Aller, J. Y., Bertram, A. K., Knopf, D. A., and Murray, B. J.: A marine biogenic source of atmospheric ice-nucleating particles, Nature, 525, 234-238, 10.1038/nature14986, 2015.

1140 Wragg, N. M., Tampakis, D., and Stolzing, A.: Cryopreservation of Mesenchymal Stem Cells Using Medical Grade Ice Nucleation Inducer, Int. J. Mol. Sci., 21, 10.3390/ijms21228579, 2020.

Yadav, S., Venezia, R. E., Paerl, R. W., and Petters, M. D.: Characterization of Ice-Nucleating Particles Over Northern India, J. Geophys. Res.-Atmos., 124, 10467-10482, 10.1029/2019JD030702, 2019.

Yakobi-Hancock, J. D., Ladino, L. A., and Abbatt, J. P. D.: Feldspar minerals as efficient deposition ice nuclei, Atmos. Chem. 1145 Phys., 13, 11175-11185, 10.5194/acp-13-11175-2013, 2013.

Zhao, X., Liu, X., Burrows, S. M., and Shi, Y.: Effects of marine organic aerosols as sources of immersion-mode ice-nucleating particles on high-latitude mixed-phase clouds, Atmos. Chem. Phys., 21, 2305-2327, 10.5194/acp-21-2305-2021, 2021.

Zinke, J., Salter, M. E., Leck, C., Lawler, M. J., Porter, G. C. E., Adams, M. P., Brooks, I. M., Murray, B. J., and Zieger, P.: The development of a miniaturised balloon-borne cloud water sampler and its first deployment in the high Arctic, Tellus. B.

1150 Chem. Phys., 73, 1-12, 10.1080/16000889.2021.1915614, 2021.

Zolles, T., Burkart, J., Hausler, T., Pummer, B., Hitzenberger, R., and Grothe, H.: Identification of ice nucleation active sites on feldspar dust particles, J Phys Chem A, 119, 2692-2700, 10.1021/jp509839x, 2015. 